\title{
CAMA
}

Centre for Applied Macroeconomic Analysis

\section{Subdued Potential Growth: Sources and Remedies}

\section{CAMA Working Paper 24/2020 March 2020}

Sinem Kilic Celik

Prospects Group, World Bank

\section{M.Ayhan Kose}

Prospects Group, World Bank

Brookings Institution

\section{CEPR}

Centre for Applied Macroeconomic Analysis, ANU

Franziska L. Ohnsorge

Prospects Group, World Bank

CEPR

Centre for Applied Macroeconomic Analysis, ANU

\section{Abstract}

Global potential output growth has been flagging. At 2.5 percent in 2013-17, post-crisis potential growth is 0.5 percentage point below its longer-term average and 0.9 percentage point below its average a decade ago. Compared with a decade ago, potential growth has declined 0.8 percentage point in advanced economies and 1.1 percentage point in emerging market and developing economies. The slowdown mainly reflected weaker capital accumulation but is also evidence of decelerating productivity growth and demographic trends that dampen labor supply growth. Unless countered, these forces are expected to continue and to depress global potential growth further by 0.2 percentage point over the next decade. A menu of policy options is available to help reverse this trend, including comprehensive policy initiatives to lift physical and human capital and to encourage labor force participation by women and older workers. 


\section{Keywords}

Potential growth, potential output, advanced economies, emerging market and developing economies.

\section{JEL Classification}

O40, O47, E20

\section{Address for correspondence:}

(E) cama.admin@anu.edu.au

\section{ISSN 2206-0332}

The Centre for Applied Macroeconomic Analysis in the Crawford School of Public Policy has been established to build strong links between professional macroeconomists. It provides a forum for quality macroeconomic research and discussion of policy issues between academia, government and the private sector.

The Crawford School of Public Policy is the Australian National University's public policy school, serving and influencing Australia, Asia and the Pacific through advanced policy research, graduate and executive education, and policy impact. 


\title{
Subdued Potential Growth: Sources and Remedies
}

\author{
Sinem Kilic Celik, M. Ayhan Kose, and Franziska Ohnsorge*
}

This version: March 2020

\begin{abstract}
Global potential output growth has been flagging. At 2.5 percent in 2013-17, post-crisis potential growth is 0.5 percentage point below its longer-term average and 0.9 percentage point below its average a decade ago. Compared with a decade ago, potential growth has declined 0.8 percentage point in advanced economies and 1.1 percentage point in emerging market and developing economies. The slowdown mainly reflected weaker capital accumulation but is also evidence of decelerating productivity growth and demographic trends that dampen labor supply growth. Unless countered, these forces are expected to continue and to depress global potential growth further by 0.2 percentage point over the next decade. A menu of policy options is available to help reverse this trend, including comprehensive policy initiatives to lift physical and human capital and to encourage labor force participation by women and older workers.
\end{abstract}

JEL Classification: O40, O47, E20

Keywords: Potential growth, potential output, advanced economies, emerging market and developing economies

\footnotetext{
* Kilic Celik (Prospects Group, World Bank; skiliccelik@,worldbank.org), Kose (Prospects Group, World Bank; Brookings Institution; CEPR; CAMA; akose@worldbank.org); Ohnsorge (Prospects Group, World Bank; CEPR; CAMA; fohnsorge@worldbank.org. We thank Martin Bailey and Zia Qureshi for their detailed comments. We appreciate feedback from Eduardo Borenzstein, Kevin Clinton, Brahima Coulibaly, Antonio Fatas, Thomas Helbling, Homi Kharas, Ugo Panizza, and Jonathan Temple. Xinghao Gong provided excellent research assistance. The findings, interpretations and conclusions expressed in this paper will be entirely those of the authors and should not be attributed to the World Bank, its Executive Directors, or the countries they represent.
} 


\section{Introduction}

The global economy regained some strength over the period between mid-2016 and 2018 but potential output growth - the rate at which an economy would grow when labor and capital are fully employed - has continued to remain weak (Figure 1). Post-crisis (201317), global potential growth fell short of its long-term average and was well below its precrisis average. This weakness was broad-based, affecting both advanced economies, where it was evident even before the financial crisis, and emerging market and developing economies (EMDEs), where there was a short-lived pre-crisis uptick.

Since the growth rate of per capita potential output is the overriding long-run force for sustained reductions in poverty, this trend is also cause for concern about the international community's ability to meet broader development goals. ${ }^{1}$ In some regions, especially commodity-exporting ones, such as Eastern Europe and Central Asia, and the Middle East and North Africa, the post-crisis slowdown in potential growth could set back per capita income convergence by more than a decade.

Against this backdrop, this paper addresses the following questions. First, how has potential growth evolved since the turn of the century? Second, what have been the drivers of potential growth? Third, what are the prospects for potential growth? Fourth, what policy options are available to lift potential growth?

To help answer these questions, the paper examines the evolution of potential growth in a large sample of countries, with a strong regional focus. Since potential output is not directly observable, economists estimate it from long time series of actual output, employment, capital stocks, and productivity. The paper uses a comprehensive database of potential output growth by Kilic Celik et al. (forthcoming). ${ }^{2}$ For clarity, and in keeping with a longer-term focus, this study uses the production function approach. ${ }^{3}$

This paper makes several contributions to the large literature on potential growth. First, the focus in this study is on the broader EMDE universe, whereas other studies have documented a potential growth slowdown in advanced economies and Asian economies. (IMF 2015; Dabla-Norris et al. 2015; Asian Development Bank 2016; and OECD 2014). Second, the paper examines global trends in the structural drivers of potential growth, including total factor productivity (TFP) growth, labor supply growth, and investment in human and physical capital. Third, it explores policy options to lift potential growth. These include measures to improve education and reforms to health care and labor

\footnotetext{
${ }^{1}$ Research suggests that two-thirds of cross-country differences in growth of the poorest households' income are accounted for by differences in average income growth (Dollar, Kraay, and Kleineberg 2013; Barro 2000). Mechanisms by which overall growth helps reduce inequality differ but include its impact in raising the demand for agricultural output which helps poor land holders, as well as rising urbanization and higher wages (Yankow 2006; Gould 2007; Ravallion and Datt 2002).

${ }^{2}$ Most of the existing literature on potential growth involves estimating the role of output gaps in driving inflation or domestic monetary policy in the context of individual countries (in about half of 67 publications for individual EMDEs surveyed by the authors).

${ }^{3}$ Other measures of potential growth incorporate short-term supply shocks that dissipate over time (Kilic Celik et al. forthcoming).
} 
markets. In contrast to earlier studies, the discussion of policy options to lift potential growth is directly derived from the empirical exercise. ${ }^{4}$

The paper's principal conclusions are as follows. First, the global financial crisis has ushered in a period of persistently weak potential growth. During 2013-17, global potential growth (2.5 percent a year) fell 0.5 percentage point below its longer-term (1998-2017) average, and even further below its average a decade ago (2003-07). Potential output decelerated in advanced economies to 1.4 percent a year during 2013-17, which is 0.5 percentage point below its long-term average. Similarly, EMDE potential growth slowed to 4.8 percent a year, 0.6 percentage point below its longer-term average. This weakness in potential growth has been broad-based, affecting almost half of EMDEs and 87 percent of advanced economies in the sample, together representing 69 percent of global GDP.

Second, a host of factors have contributed to this post-crisis shortfall in potential growth below longer-term averages. Half of the deceleration reflects weaker-than-average rates of capital accumulation. Just over one-quarter of the slowdown is due to weaker total factor productivity (TFP) growth while just under one-quarter of the moderation is attributable to demographic trends.

Third, the slowdown in potential growth may extend into the next decade. Trends in its fundamental drivers suggest that global potential growth may slow further by 0.2 percentage point on average over 2018-27. While the decline in potential growth is expected be 0.1 percentage point a year in advanced economies, EMDE potential growth could ease much more, by 0.5 percentage point. The projected slowdown from 2013-17 would affect EMDEs and advanced economies that account for 73 percent of global GDP.

Fourth, policies could help reverse these trends and boost global growth. For advanced economies, labor market reforms (especially targeting pension systems) may have the highest potential to stem the decline in potential growth. Among EMDEs, in particular, education, health, and labor market reforms could significantly increase potential growth. A combination of these policies could lift potential growth in EMDEs over the next decade by 0.8 percentage point, and more in EAP and ECA.

To sustain higher potential growth, countries need to reform labor and product markets, strengthen human and physical capital and build conducive environments for business and households to invest. The onus is particularly on the largest emerging markets and advanced economies, whose growth momentum generates spillovers for other EMDEs.

This paper draws on a comprehensive database that estimates potential growth using all standard approaches for up to 181 countries for 1980-2017 (extending to 2027 for 80 countries) based on Kilic Celik et al. (forthcoming). For clarity, the remainder of the paper presents only results using a production function approach for 30 advanced economies and 50 emerging market and developing economies for 1998-2027 that together

\footnotetext{
${ }^{4}$ Other studies have investigated the link between actual growth or productivity growth and structural reforms, focusing on the near-term benefits (Prati, Onorato, and Papageorgiou 2013), productivity effects (Dabla-Norris, Ho, and Kyobe 2015; Adler et al. 2017) or a sample consisting of mostly advanced economies (Banerji et al. 2017; IMF 2015 and 2016b).
} 
account for 91 percent of global GDP. ${ }^{5}$

\section{Evolution of Potential Growth: What Happened?}

\subsection{Slowdown in global potential growth}

Global potential growth fell to 2.5 percent a year during 2013-17. This is below its longerterm (1998-2017) average of 3 percent a year and even further below its average a decade earlier (2003-07; Figure 2). The potential growth weakness was broad-based and robust to the specific choice of potential growth measures. During 2013-17, potential growth was below its longer-term average in 87 percent of advanced economies and in almost half of EMDEs. Economies with potential growth below its longer-term average accounted for roughly 70 percent of global GDP.

Per capita estimates also show a trend deceleration. These estimates suggest that there was a persistent slowdown in global potential growth beneath the temporary cyclical shocks that appear to have been the main reasons for the post-crisis slowdown in actual growth from elevated pre-crisis levels. In advanced economies, the potential growth slowdown set in before the global financial crisis whereas EMDEs enjoyed a short-lived pre-crisis surge in potential growth that subsequently faded.

Among advanced economies, following a sharp decline during 2008-12 - the period of the global financial crisis, the Euro Area crisis, and pronounced investment weaknesspotential growth stabilized in 2013-17 as investment growth recovered. ${ }^{6}$ However, at 1.4 percent a year over 2013-17, potential growth in advanced economies remains about 0.5 percent-age points below its longer-term average. The decline was particularly pronounced in some countries in Asia.

In EMDEs, in the initial wake of the global financial crisis, a surge in public investment underpinned EMDE potential growth, offsetting softening productivity and labor supply growth. As EMDE policy stimulus was unwound, and as investment growth plummeted in commodity-exporting EMDEs following the oil price slide in mid-2014, EMDE potential growth slowed sharply to 4.8 percent a year in 2013-17, 0.6 percentage point below its longer-term average. ${ }^{7}$

\footnotetext{
${ }^{5}$ The 50 EMDEs include 4 economies in East Asia and the Pacific, 9 economies in Europe and Central Asia, 15 economies in Latin America and the Caribbean, 7 economies in the Middle East and North Africa, 2 economies in South Asia and 13 economies in Sub-Saharan Africa (Kilic Celik et al. forthcoming). Please see Table 1 for the list of countries in each group and region. Data for more than one-third of them (and about half of the sample's EMDEs in Europe and Central Asia and Sub-Saharan Africa) is missing before 1997 and no data for EMDEs is available before 1991. Hence, to ensure broad country coverage, the sample period is restricted to 1998-2027.

${ }^{6}$ As in the broader set of advanced economies, potential growth in G7 economies - Canada, France, Germany, Italy, Japan, United Kingdom, and United States - was, at 1.5 percent on average in 2013-17, 0.3 percentage points below its longer-term average.

${ }^{7}$ The potential growth slowdown from pre-crisis rates was also evident in EM7 economies-Brazil, China, India, Indonesia, Mexico, Russia, and Turkey. On average during 2013-17, EM7 potential growth slowed to 5.4 percent. Almost three-quarters of this decline in EM7 potential growth between 2003-07 and 2013-17 reflected slowing potential growth in China.
} 


\subsection{Regional heterogeneity}

Potential growth has fallen furthest in EMDE regions that had benefited from rapid per capita income convergence or that hosted many commodity-exporting EMDEs (Figure 3). The shortfall of potential growth during 2013-17 from its longer-term (1998-2017) average was one of the sharpest in the Middle East and North Africa (MNA, 1.2 percentage point) where investment growth plunged amid the oil price drop of mid-2014, a period of violent conflict and policy uncertainty in parts of the region.

During 2013-17, potential growth also fell 0.5 and 0.2 percentage points, respectively, below its longer-term average in Europe and Central Asia (ECA) and Latin America and the Caribbean (LAC). The ECA region's past two decades of rapid integration into European production networks has gradually diminished its potential for further catchup productivity growth. The region also hosts several energy exporters which suffered deep recessions or slowdowns following the mid-2014 decline in oil prices. Weak productivity growth and less favorable demographics reduced potential growth in LAC. ${ }^{8}$

In EAP, in 2013-17, potential growth in China fell 1.3 percentage points below its longerterm average as policy efforts succeeded in rebalancing growth away from investment towards more sustainable growth engines, combined with slowing productivity and working-age population growth. Elsewhere in EAP, potential growth rose 0.7 percentage point on robust capital accumulation and strengthening TFP growth.

During 2013-17, favorable demographics have helped lift potential growth in South Asia (SAR) and Sub-Saharan Africa (SSA). In SAR, potential growth was negatively affected by investment weakness such that growth in 2013-17 broadly matched its longer-term average. In SSA, potential output accelerated by 0.4 percentage point during 2013-17 compared to its longer-term average. This demographic dividend was complemented by rapid capital accumulation over the past two decades as resource discoveries were developed into operating mines and oil fields, and governments undertook large-scale public infrastructure investments. The commodity price slide after 2011 has raised concerns about the sustainability of such potential growth.

\section{Drivers of the Slowdown in Potential Growth}

Of the 0.5 percentage-point shortfall in post-crisis (2013-17) global potential growth below its longer-term (1998-2017) average, about one-half can be attributed to weaker capital accumulation (0.2 percentage point) and the remainder to weaker TFP growth and slower labor supply growth (0.1 percentage point, respectively; Figure 4). Weak global capital accumulation mainly reflected investment weakness in advanced economies, in the wake of financial crises in the United States and Europe, and a policy-driven rebalancing away from investment in China. Unfavorable demographics and slowing TFP growth were features of both advanced economies and EMDEs (Figure 4).

\footnotetext{
${ }^{8}$ In contrast to production function-based potential growth measures, potential growth estimates based on filtering techniques have slowed sharply in LAC and SSA. The predominantly host commodity exporters, where actual growth decelerated steeply in the commodity price slide from 2011.
} 


\subsection{Total factor productivity growth}

By allowing output to expand with a given amount of factor inputs, TFP growth has historically been the critical driver of sustained growth in per capita output and prosperity (Romer 1986; Lucas 1988; Grossman and Helpman 1991). TFP growth can rise with the adoption of new technologies, adaptation of existing technologies, introduction of more efficient processes, or changes in management practices (EBRD 2014). Differences in TFP account for about two-thirds of the variation in per capita income across the world (Jones 2016). Higher productivity lifts firms' marginal product and reduces their marginal cost, which allows firms to increase their demand for factors of production. Technological advances reduce the price of capital equipment, encouraging further capital accumulation which, in turn, embodies further improvements in productivity (Greenwood, Hercowitz, and Krusell 1997; Sakeflaris and Wilson 2004).

Global potential TFP growth - the part of TFP growth that is stripped of its wide cyclical swings - slowed from about 1.3 percent a year a decade ago to about 1 percent a year during 2013-17, but with wide heterogeneity (Figure 5). In advanced economies, productivity growth showed signs of flattening well before the global financial crisis. For some advanced economies, the productivity growth slowdown during the early 2000s has been described as a return to productivity growth before the surge of information and communications technologies in the mid-1990s (Gordon 2013; Cette, Fernald, and Mojon 2016)..$^{9}$

By contrast, TFP growth in EMDEs surged to 2.5 percent a year a decade ago (2003-07), reflecting productivity-enhancing investment, partly financed by capital inflows. ${ }^{10}$ Reforms of policy frameworks after EMDE financial crises in the late 1990s and early 2000s and greater integration into global value chains provided a conducive environment for rapid productivity growth. However, since the global financial crisis, TFP growth in EMDEs has slowed to 1.9 percent a year in 2013-17.

Some drivers of the TFP growth slowdown are likely to be structural and persistent. TFP growth may have slowed as a wave of information and communications technologies matured. The pace of cross-country diffusion of technology may have diminished as global value chains stopped growing. Aging workforces may have impeded the adoption of new ideas. In commodity exporters, a downgrading of expectations for long-term profitability of resource projects would have reduced investment and, with it, embodied productivity gains. Finally, the large-scale factor reallocation, especially from agriculture to manufacturing, that has supported robust EMDE productivity growth over the past two decades appears to be slowing.

Over the past three decades, TFP growth in EMDEs has been supported by growing human capital. Among a better-educated and healthier working-age population, both TFP growth and labor force participation rates tend to be higher. EMDEs have made rapid

\footnotetext{
${ }^{9}$ Baily and Montalbano 2016 attribute (some of the) surge in the US productivity growth in the mid-1990s to improvements in productivity measurement especially in services sector.

10 The regression results suggest that for many EMDEs, catchup productivity growth is a key driver of overall TFP growth (for details, see Kilic Celik et al. forthcoming).
} 
strides towards improving education and health outcomes over the past two decades. On average in EMDEs, secondary school completion rates have increased by 7 percentage points between 1998-2002 and 2013-17. At 27 percent, this is about two-thirds of the advanced-economy average. Tertiary completion rates have risen by about one-half to 10 percent in 2013-17, but still about half of the advanced-economy average. Life expectancy has risen by 4 years to 71 years, about 10 years short of the advanced-economy average.

These substantial improvements in human capital mitigated adverse developments weighing on EMDE potential growth between 1998-2002 and 2013-17, and helped raise potential growth in regions where progress was particularly large. The largest improvements between 1998-2002 and 2013-17 were made in SSA, where secondary completion rates almost doubled (by 7 percentage points) to approach the advancedeconomy average, and life expectancy rose by 7 years to almost 60 years. Life expectancy also rose considerably (4 years) in South Asia to 72 years.

\subsection{Physical capital accumulation}

Investment can lift potential output growth through direct and indirect channels. Directly, investment is the source of capital accumulation, which raises labor productivity and potential output - provided investment is not channeled into excess capacity and wasted (Devarajan, Swaroop, and Zhou 1996; Presbitero 2016). Indirectly, investment can raise total factor productivity because technological improvements are often embodied in investment (Solow 1962).

Global investment growth halved between 2010 and 2016, with the investment weakness shifting from advanced economies to EMDEs over this period. Investment growth in advanced economies declined during the Euro Area crisis and, after a brief rebound, again after the oil price decline that disrupted energy sector investment in the United States. In EMDEs, investment growth slowed sharply following the global financial crisis, from double-digit rates in the immediate wake of the crisis to a post-crisis low of 3 percent in 2016 (Islamaj et al. 2019). Despite signs of bottoming out in 2017, investment growth has been well below its pre-crisis average as well as its longer-term average in more than half of EMDEs in the sample (Figure 6). In EMDEs, both public and private investment were weak. Public investment accounted for about 31 percent of total investment in EMDEs and about 15 percent of advanced-economy investment during 2010-15 (World Bank 2017a). After 2011, public investment growth remained anemic following the stimulusrelated surge of 2008-09 and private investment growth slowed sharply after 2011.

Whereas investment weakness in advanced economies mainly reflected sluggish demand and output growth, in EMDEs a broader range of factors has been at play. In commodity importers, slowing FDI inflows and spillovers from soft activity in major advanced economies accounted for much of the slowdown in investment growth after 2011. In commodity exporters, a sharp deterioration in their terms of trade (particularly for energy exporters), slowing growth in China, and mounting private debt burdens accounted for much of the slowdown in investment growth. In several EMDEs, political and policy uncertainty was a key factor in investment contractions or slowdowns (Kose et al. 2017). Investment weakness may also reflect the declining price of capital goods or a growing 
role of poorly-measured intangible capital, such as design, research and developments, marketing and training (Corrado and Hulten 2010; Ollivaud, Guillemette, and Turner 2016).

Cyclical factors, although transitory in themselves, can have long-lasting effects on potential output growth. More than half of EMDEs in the sample suffered at least one year of investment contraction during 2013-17. In some, investment contractions were triggered by the prolonged slump of commodity prices from their peak in early 2011. In others, it was accompanied by heightened domestic political or geopolitical tensions. Such episodes typically foreshadow weaker potential growth in the three years surrounding the trough of the investment contraction.

\subsection{Labor supply}

Growing working-age populations have been associated with "demographic dividends" to growth. Higher working-age shares of populations have been accompanied by higher capital accumulation and employment (Bloom and Canning 2004; IMF 2004; Figure 7). ${ }^{11}$ Shifts towards an older age structure of the population affect potential output in several ways. Population aging may reduce the working-age population, which directly reduces potential labor supply. There are also less direct effects of population aging. For example, aging increases the share of the population with below-average labor force participation rates. Aging populations have been associated with slower labor productivity growth for various industries and occupations (Maestas, Mullen, and Powell 2016).

Another important driver of increased labor supply can be labor force participation among less represented groups, including women, young, and old workers. Rising female labor force participation rates have been attributed to better educational attainment (opening access to higher-earning jobs), lower fertility rates, a technology-driven shift toward nonmanual skills, and cheaper home production (lowering the opportunity cost of working). ${ }^{12}$ Meanwhile, population aging has contributed to a decline in labor force participation, which tends to be lower among older workers (Maestas, Mullen, and Powell 2016).

In the past five decades, growth was supported by rapidly growing working-age populations - until the mid-1980s in advanced economies and around 2010 in EMDEs (Figure 7). Since 2000, countries with rising working-age population shares accounted for half of global output growth and three-quarters of global GDP levels. With the retirement of the baby boom generation and lower fertility rates, demographic trends have turned less favorable to growth and will continue to do so over the next decade (Kose and Ohnsorge 2019). In advanced economies, the working-age share of the population is set to

\footnotetext{
${ }^{11}$ The benefits from a rising working-age population have been particularly pronounced in Asia (Bloom et al. 2010; Bloom et al. 2007; Aiyar and Mody 2011). Demographic change over the period 1960-1995 for 86 countries has been estimated to have accounted for approximately 20 percent of per capita output growth, and more in Asia and Europe (Kelly and Schmidt 2005). Cruz and Ahmed (2016) estimated that a 1-percentage-point increase in the working-age population share was associated with a more-than-proportional increase in GDP per capita growth in 160 countries over 1960-2010. Other studies of the relationship between demographics and growth include Higgins and Williamson (1997); Eastwood and Lipton (2011); and Kelley and Schmidt (1995 and 2007).

${ }^{12}$ These factors have been explored in Mincer (1962); Goldin (1994); Hill (1983); Killingsworth and Heckman (1986); and Connelly (1992).
} 
decline, from 65.4 percent in 2015 to 62.3 percent by 2025. In EMDEs, the working-age share of the population peaked at 65.8 percent in 2015 and is expected to stabilize around this level for the next 10 years. While the largest declines are expected in EAP and ECA, working-age shares of the population are expected to rise in Sub-Saharan Africa and South Asia.

In addition to the changing age composition of the population, expanding female labor force participation has increased labor supply, especially in EMDEs. Female labor force participation has been broadly stable over the two decades from 1998-2002 to 2013-17, however with a wide divergence across EMDE regions. Supported by surging school enrollment and completion rates, female labor force participation rates in LAC rose by almost 6 percentage points between 1998-2002 and 2013-17. In contrast, despite some (more modest) improvements in education, they declined in SAR by almost as much over the same period. Among EMDEs, female labor force participation remains less than threequarters of male labor force participation.

The overall effect of demographics on potential growth - via TFP growth and labor supply growth - can be assessed using the production function approach. The estimates compare baseline potential growth estimates against counterfactual scenarios in which the composition of the population for all age groups and genders remains at their 1998 values. ${ }^{13}$

The contribution of aging to potential growth is calculated as the difference between actual potential growth and a counterfactual derived from an "unchanged demographics" scenario. The counterfactual scenario is one in which population shares are fixed at 1998 levels (for historical contributions) or 2017 levels (for forward-looking scenarios) in the calculation of labor force participation rates and TFP growth. All other variables, including fitted labor force participation rates for each age group and gender, remain the same in both scenarios. Hence, aggregated labor supply differs between the two scenarios only because different age groups (with different inclinations to participate in the labor force) have different population shares.

The contribution of migration to potential growth is calculated as the difference between actual potential growth and a counterfactual derived from an "no-migration" scenario. The counterfactual scenario is one in which population, population shares, fertility, and life expectancy indicators are estimated under zero international migration for each country, as calculated in the UN Population Statistics.

The results suggest that, in 2013-17, population aging has lowered global potential growth by 0.2 percentage point from its 2003-07 average. Advanced economies accounted for all of this decline. In EMDEs, with the exception of ECA, growing and younger working-age populations lifted potential growth marginally over the same period. Trends in female labor force participation benefited some EMDE regions' potential growth while weighing on potential growth in others. Over the longer-term (1998-2017), higher female labor force participation contributed 0.3 percentage point to potential growth in LAC, while it did

\footnotetext{
${ }^{13}$ Such thought experiments are widely used to assess the impact of demographics on growth or growth projections (Bloom, Canning, and Fink 2010; European Commission 2015).
} 
not contribute appreciably to longer-term potential growth in SAR.

\section{Prospects for Potential Growth: What Could Happen?}

Factors weighing on potential growth over the past five years are likely to persist over the next decade. Demographic trends are expected to become less favorable. This will weigh on potential growth even if trend improvements in human capital and female labor force participation (and, for advanced economies, migration) continue. Although investment growth is expected to recover from its recent weakness, it is unlikely to return to elevated pre-crisis levels. Short of unexpected surges in productivity growth-perhaps as a result of dissipating crisis legacies or unanticipated technological breakthroughsthese trends imply an outlook for mediocre potential growth. This is also reflected in repeated downgrades to global growth forecasts (Kose, Ohnsorge, and Sugawara forthcoming).

The forward-looking scenario presented here applies the production function approach to assumed paths for capital, population statistics, and education and health outcomes (Kilic Celik, Kose and Ohnsorge 2020). The baseline scenario is one of "follow the same path" in that it assumes that all policy variables follow their long-term average trends.

The scenario assumes that all population-related variables (including age and gender structure of the population, fertility, and life expectancy) evolve as in the UN Population Projections under the assumption of median fertility, normal mortality, and "normal" (i.e. trend) migration. ${ }^{14}$

Past trend improvements in each economy's education and health outcomes are expected to continue. Secondary and tertiary enrollment rates by gender are assumed to grow through the forecast horizon at their average growth during 1998-2017 but are capped at 100 percent. Economy-wide averages are calculated as the population-weighted (2000-16) average of these gender-specific rates.

Secondary and tertiary education completion rates by gender and age group are assumed to grow at their average rate during 1998-2017. Economy-wide averages are calculated as the population-weighted (2000-16) average of these gender and group-specific rates.

In line with historical experience, investment growth is assumed to remain constant at its long-term average. ${ }^{15}$

Under this baseline scenario, the fundamental drivers of potential growth all point to continued softening. A slowing pace of capital accumulation, especially in China, will be offset by growing capital accumulation in advanced economies. In EMDEs other than China, the pace of capital accumulation will remain broadly steady as investment growth keeps pace with recovering output growth after its pronounced weakness of 2015-16. Subdued investment and less room for catchup productivity growth as per capita income

\footnotetext{
${ }^{14}$ Cohort effects are assumed to stay constant at their latest level throughout the forecast horizon, starting in 2018 .

${ }^{15}$ Considering the policy-driven rebalancing away from investment in China, investment growth rates are assumed to be constant at their last five-year average (2013-17).
} 
differentials narrow for EMDEs will sap productivity growth. This could reduce potential growth by about 0.1 percentage point. Even if education and health outcomes continue to improve in line with their longer-term trends, aging populations combined with withdrawal from the labor market of older cohorts of workers could reduce global potential growth by another 0.2 percentage point on average. That said, in advanced economies, migration could dampen the slowdown in potential growth by about 0.1 percentage point by supporting labor force growth.

Thus, absent significant policy changes or productivity breakthroughs, global potential growth could decline by 0.2 percentage point, to 2.3 percent a year in 2018-27 (Figure 8). Two-thirds of the sample's economies, accounting for 78 percent of global output, would be left with potential growth below the longer-term average.

Advanced-economy potential growth could slow by 0.1 percentage point to 1.3 percent a year. This deceleration in potential output mostly reflects an expected decline in TFP growth and a further slowdown in labor supply due to population aging. These trends are expected to be only partially offset by a recovery in capital accumulation from post-crisis weakness.

EMDE potential growth could slow by 0.5 percentage point to average 4.3 percent a year during the next decade, well below its longer-term average. This slowdown would mostly reflect demographic trends (across most EMDEs) and weaker capital accumulation in China, as China's policy-guided investment slowdown continues (elsewhere capital accumulation is expected to recover partially from its post-crisis weakness). While China will account for 0.4 percentage point of the 0.5-percentage-point decline in EMDE potential growth, the decline will be broad-based, affecting almost two-thirds of EMDEs in the sample.

The slowdown would also be sizable for the largest EMDEs, which could generate adverse spillovers to other EMDEs that the production function approach does not explicitly account for ${ }^{16}$ Largely owing to weakening demographic trends and China's slowing capital accumulation, potential growth in the seven largest emerging markets (EM7) is expected to slow by 1.1 percentage point on average, of which China accounts for more than threequarters. Aging (and, in some cases, shrinking) populations are expected to reduce G7 potential growth by 0.2 percentage point on average.

Potential growth is expected to slow over the next decade in all regions and fall below the longer-term average in all regions except SSA. In most regions, working-age shares of the population are expected to shrink. In SAR and SSA, working-age shares of the population are expected to rise, but a shift is expected within the working-age population towards older cohorts with weaker labor market attachment.

Potential growth is expected to moderate in EAP as policy efforts in China succeed

\footnotetext{
${ }^{16}$ A 1-percentage-point decline in growth in the seven largest emerging markets (EM7) could slow growth in other EMDEs by 0.9 percentage point over the following three years. A similarly-sized decline in G7 growth could have a one-half to three times larger impact than an EM7 slowdown (Huidrom, Kose, and Ohnsorge 2017). EM7 countries include China, Russia, India, Brazil, Turkey, Mexico, and Indonesia.
} 
shifting towards more sustainable growth engines, and the region's working-age population ages. China's potential growth is expected to slow to 6.5 percent, on average in 2018-27, from 9.1 percent on average during 1998-2017 (Figure 4). Elsewhere in EAP, potential growth is expected to remain solid. In LAC, demographic trends and the legacy of weak investment over the past half-decade will weigh on potential growth.

Shrinking labor supplies and weak investment will weigh on potential growth in ECA and SAR as investment fails to return to the elevated levels seen before the oil price plunge and onset of policy uncertainty in mid-2014. In SSA, an expected slowdown in potential growth largely reflects population aging in South Africa, while elsewhere in SSA potential growth is expected to remain broadly steady at a robust 5 percent.

Potential growth is expected to strengthen somewhat in the Middle East and North Africa. Investment and productivity growth are expected to firm, provided conflict and geopolitical risks do not intensify.

\section{Policy Options to Lift Potential Growth}

The production function framework can be applied to examine stylized policy scenarios. The impact of better policy outcomes is estimated as the difference between potential growth under a counterfactual scenario of higher growth of physical or human capital or labor supply compared with the baseline scenario. All counterfactual scenarios model a repeat of a country's best ten-year improvement, up to reasonable ceilings. The potential growth dividend of the scenarios therefore depends on each country's track record as well as its room for improvement. The estimate provided in these stylized scenarios may well be lower bounds because they disregard nonlinearities in reform impacts as well as synergies between different reform measures.

The investment growth rate in each country is assumed to rise by its highest increase in any ten-year period during 1998-2017.

Educational outcome indicators - secondary and tertiary enrollment and completion rates - are assumed to rise in each country by as much as the maximum improvement over any ten-year period during 1998-2017. Enrollment rates remain capped at 100 percent. Completion rates are capped at the maximum across advanced economies in 2016. Life expectancy is assumed to rise in each country as much as the largest improvement over any ten-year period during 1998-2017, but not above the median advanced-economy life expectancy in 2016 (capped at 100 years).

For each age group in each country, female labor force participation rates are assumed to rise by the largest increase over any ten-year period during 1998-2017, but not to exceed male labor force participation rates in the same age group. Separately, a pension reform with labor market implications is modelled. For each gender and each country, labor force participation rates for workers in the age groups of 55,60, and 65 years or older are assumed to rise to the rates of age groups that are 5 years younger, i.e. those of the age groups of 50, 55, and 60 years. The increase is assumed to occur gradually over 20 years for each gender in each country. 


\subsection{Raising physical capital}

UNCTAD (2014) estimated that unfilled global investment needs amount to up to 3 percent of global GDP. In particular, all EMDE regions have sizable investment needs (Vashakmadze et al. 2017). Depending on the availability of financing, these could be filled through either public or private investment or a combination of both in publicprivate partnerships. Increasing public investment can be an effective policy tool to support short-term demand while also helping to raise future potential growth (World Bank 2017a; Calderón and Servén 2010a, 2010b, and 2014). Although the rapid increase in public debt over the past decade has constrained fiscal space in most countries, there remains scope to shift existing government expenditures toward public investment to make government operations more growth-friendly (World Bank 2017b; Kose et al. 2019). Moreover, in many countries, government revenue ratios remain low, indicating that in some cases tax revenues could be raised, including by expanding tax bases or improving the quality of tax administration (World Bank 2015).

In addition, policies can support productivity-enhancing private investment. Innovationrelated investment tends to be low in EMDE firms, partly because of limited availability of complementary inputs such as trained engineers or effective organization techniques (Cirera and Maloney 2017). Policy efforts to expand the supply of complementary inputs and capabilities and to raise the returns on investment through intellectual property right protection may foster private investment.

If, over the next decade, each country raised its investment growth as much as its largest increase over any historical ten-year interval, global investment-to-GDP ratios would rise by 2.3 percentage points of GDP. Investment-to-GDP ratios would rise somewhat more in EMDEs, by 2.9 percentage points of GDP. It is estimated that such an investment boost would raise global potential output by 2 percent by 2027 , reversing the slowdown under the baseline scenario. EMDE potential output would rise even more ( 5 percent cumulatively by 2027; Figure 9).

Implicit in these scenarios is the premise that the additional investment will be used productively. In the context of EMDEs, there is some evidence that absorptive capacity can limit the success of large scaling-up of public investment, although this adverse effect is small in lower-income and capital-scarce countries (Presbitero 2016).

\subsection{Raising human capital}

Measures to raise human capital could lift both labor supply and TFP growth: A better educated workforce is more securely attached to the labor market and more productive. In particular, a better-educated workforce may be better able to adjust to technological disruptions that reduce employment and wages by replacing jobs (Acemoglu and Restrepo 2017a). ${ }^{17}$ In the framework used here, human capital has two dimensions, educational

\footnotetext{
${ }^{17}$ The impact of such technological disruptions on output may not be clear-cut. For example, in aging societies, technological change to replace jobs may relieve pressures resulting from a shrinking labor supply (Acemoglu and
} 
attainment and health outcomes (proxied by life expectancy).

\section{Education}

While secondary school enrollment rates are near advanced-economy levels in the average EMDE, tertiary school enrollment rates (40 percent) and secondary and tertiary school completion rates (27 and 10 percent, respectively) were less than two-thirds of the advanced-economy average in 2013-17 on average. In addition to expanding access to education, such as captured by these measures, improving the quality of education to improve education outcomes is critical (World Bank 2017c).

There are a number of policies that can improve education outcomes. At the national level, these include policies targeted at better training for teachers, greater teacher accountability, and performance incentives (Evans and Popova 2016). The development of metrics to assess and accelerate progress toward learning goals is a prerequisite for policy actions to improve educational outcomes (World Bank 2017c). ${ }^{18}$ At the studentlevel, useful policies include efforts to tailor teaching to the requirements of students (Kremer, Brannen, and Glennerster 2013). Grants may encourage school attendance by disadvantaged students (Glewwe and Marulidharan 2015). Better early childhood nutrition and cognitive development improve students' capacity to learn (Tsimpo Nkengne, Etang Ndip, and Wodon 2017).

In a stylized policy scenario, education-related policy indicators - secondary and tertiary enroll-ment and completion rates - are assumed to rise over 2018-27 in each EMDE by as much as their largest historical improvement in any ten-year period. This would imply that EMDEs, on average, would raise secondary school completion rates by 5 percentage points and secondary and tertiary enrollment rates by 7 percentage points, on average, during the next decade. In EMDE regions that have made particularly large strides in improving education outcomes but still have ample room for further improvements, such as SAR, secondary school completion rates could rise as much as 16 percentage points over the next decade.

Rapid technological and a more interdisciplinary perspective may also require new education strategies that allow workers to be flexible and adapt their knowledge and expertise throughout their careers. More than a third of the skills demanded in today's world have been estimated to be no longer desirable for future occupations by 2020 (World Economic Forum 2016). Hence, the ability to mobilize knowledge and rapidly adapt skill sets may be a critical competency for workers to meet demands of future labor markets (OECD 2018a).

\section{Health policies}

At 71 years on average in 2013-17, life expectancy in EMDEs is still below that in

Restrepo $2017 \mathrm{~b}$ and 2017c). In addition, automation may expand labor demand by creating new tasks for which labor has a comparative advantage (Acemoglu and Restrepo 2016).

${ }^{18}$ Other measures such as reducing student-teacher ratios or additional years of schooling have effects that differ widely depending on country circumstances (Evans and Popova 2016; Hanushek and Woessman 2008). 
advanced economies (82 years). Although regions such as SAR and SSA have made large improvements, raising life expectancy by 4-7 years over the past two decades, it remains about one-eight below advanced-economy levels.

Policy interventions to improve public health, and to ensure productive working lives, range widely. Better sanitation and access to clean water would improve public health: 9 percent of the global disease burden may be attributable to unsafe water, inadequate sanitation, and insufficient hygiene (WHO 2008). In addition, improvements in health care provision can be spurred by well-defined and regularly monitored performance indicators (Bradley et al. 2010). Comprehensive coverage of health services has been followed by better health outcomes in countries with higher per capita incomes (Maeda et al. 2014).

At the local level, programs targeted at local health service providers or groups of patients have generated considerable improvements in health care services and outcomes. For example, in Rwanda, performance-based incentive payments helped significantly improve health indicators for children (Gertler and Vermeesch 2012). In India, enhanced training of primary health care providers led to better identification and treatment of patient ailments (Das et al. 2016).

In a stylized scenario of improved health, life expectancy is assumed to rise over 2018-27 in each EMDE by as much as its largest improvement over any historical ten-year period. This would imply an increase in life expectancy in EMDEs by 2.5 years, on average, but as much as 3.8 years in MNA over the next decade.

\section{Impact on potential growth}

These stylized scenarios suggest that improvements in education and health outcomesvia their effect on labor supply and TFP growth - could lift global and EMDE potential growth by 0.2 percentage point on average. In some EMDE regions with a strong track record of boosting human capital and ample room for improving education and health outcomes, such as in EAP, potential growth could rise by one-and-a-half times as much.

\subsection{Raising labor supply}

At 49 percent, on average, in 2013-17, global female labor force participation remains twothirds that of men (75 percent), and it is even lower in EMDEs. Similarly, in both EMDEs and advanced economies, the average labor force participation rate among workers aged 55 years or older is about one-half that of 30-45-year-old workers, and labor force participation among 19-29 year-olds is only four-fifths that of their 30-45-year-old peers. Labor supply can be raised by drawing a greater share of the working-age population into the labor force. This can be achieved through policies to "activate" discouraged workers or groups with historically low participation rates, such as women and younger or older workers.

In advanced economies and EMDEs, active labor market policies and reforms to social benefits were followed by higher labor force participation rates (Betcherman, Dar, and 
Olivas 2004; Card, Kluve, and Weber 2010). Less rigid employment protection regulation and lower minimum wages have had mixed effects on employment and labor force participation and, at times, unintended side effects such as lower labor force participation of disadvantaged groups (Betcherman 2014).

In EMDEs, policies aimed at other objectives have sometimes brought important collateral benefits that improve labor force participation. For example, in Nigeria, improved access to finance and training programs increased female labor force participation by encouraging firm startups (Brudevold-Newman et al. 2017). In Uruguay, the extension of the school day was associated with higher adult labor force participation (Alfaro, Evans, and Holland 2015). In Eastern Europe and Central Asia, shifting health care systems towards services targeted at the elderly has helped extend productive life times, and providing support services to women with families has helped encourage labor force participation (Bussolo, Koettl, and Sinnott 2015).

Female labor force participation rates-along cohort, age-, and country-specific dimensions - are assumed to rise, over the next decade, by the largest historical ten-year improvement in each EMDE (in a stylized labor market reform scenario), although they will not exceed the rates of same-aged men. On average, this would imply raising female labor force participation rates by 10 percentage points by 2027. The premise underlying this assumption is that, over the decade, sufficient jobs will be created to absorb this additional labor supply.

In such a stylized labor market reform scenario, global and EMDE potential growth could rise by 0.2 and 0.1 percentage point, respectively, on average, over 2018-27. Again, such a renewed reform push could yield the largest dividends for EMDE regions with both a strong track record and sizable remaining gaps between male and female labor force participation rates (e.g., LAC).

The scenario assumes a pension reform that gradually raises labor force participation in each five-year age group from 55 years onwards. Separately in each country and for each gender, labor force participation rates for workers in the age groups of 55-59 years, 60-64 years, and 65 years or older are assumed to rise to the rates of age groups that are five years younger, i.e. those of the age groups of 50-54, 55-59, and 60-64 years. The increase is assumed to occur gradually over 20 years for each gender in each country.

In such a stylized pension reform scenario, global and advanced economy potential growth could rise by 0.3 percentage point on average, over 2018-27. For EMDEs, the effect is smaller, at 0.1 percentage point. The largest boost to growth would materialize in EAP and ECA, the two regions with the most rapidly aging populations.

\subsection{Raising productivity}

The scenario analysis thus far is restricted to reforms that can be quantified in the production function framework used here. Other reforms could raise total factor productivity. Institutional reforms could help lift productivity growth. Better institutional quality, such as control of corruption, application of the rule of law, and improved political 
stability, has accompanied higher and more stable growth. At the firm-level, more friendly business climates have favored firm productivity and a shift from informal activities to more productive formal activities.

Fiscal structural reforms could also yield important productivity dividends. Several studies have highlighted the long-term growth dividends of fiscal reforms, especially when combined with other structural reforms (IMF 2016a). In OECD countries, the growthenhancing effects of a budget-neutral shift in government spending towards health, education, and transport often becomes apparent after five years (Barbiero and Cournède 2013). More broadly, low- and lower-middle-income countries with a greater share of nonwage government spending tend to have higher long-term growth (Gupta et al. 2005).

On the revenue side, also, a budget-neutral increase in the efficiency of the tax system could raise long-term growth. Sixty percent of fiscal reform episodes in 112 countriessuch as switching from labor taxation to consumption taxation and shifting spending towards health, education, and infrastructure - were followed by growth accelerations of more than 1 percentage point (IMF 2016b). Over the longer-term, fiscal reforms such as the establishment of fiscal rules have also proven growth enhancing in EU countries (Miyazaki 2014; Castro 2011; Afonso and Jalles 2012).

Kilic Celik et al. (forthcoming) finds that governance and business climate reforms are associated with increases in both potential TFP growth and investment growth. Reform spurts, which are defined as one-standard-error changes in one of the four Worldwide Governance Indicators, are followed by a statistically significant 0.1 percentage point increase in potential TFP growth and around 3 percentage points increase in investment growth two-four years after the reform spurts.

\section{Conclusion: Reforms for Growth}

The stylized scenarios above suggest that a combination of additional investment, better educational and health outcomes, labor market or business climate and governance reforms could stem or even reverse the expected decline in potential growth over the next decade (Figure 9). The human and physical capital and labor market reform scenarios above are associated with 0.7 percentage point higher global growth.

In advanced economies, reforms associated with human and physical capital and labor markets could enhance potential growth by 0.7 percentage point. Although the impact of policies aiming at readying human capital for future labor market demands is difficult to quantify for advanced economies in general, labor market reforms (especially pension reforms) may have a significant impact on potential growth going forward. In some countries, meeting physical investment needs may still yield sizable increases in potential growth.

The human and physical capital and labor market reform scenarios above are associated with 0.8 percentage point higher EMDE potential growth. For EMDEs, this would more than offset the 0.5-percentage-point slowdown in potential growth expected under the baseline scenario. Any reform package has to take into account several additional 
considerations.

Implementing multiple reforms simultaneously rather than piecemeal can generate mutually-reinforcing synergies. For example, in OECD countries, labor and product market reforms, FDI, and trade regulation potentially yield important synergies (OECD 2017). In another example, land, fiscal, and social benefit reforms yield larger growth benefits in China when implemented jointly (Ran et al. 2011). In addition, cross-country synergies from coordinated reforms may arise. The potential for growth spillovers puts a premium on reform efforts in advanced economies that have large repercussions for their EMDE trading partners.

In practice, reform priorities differ across countries, calling for tailored policies (DablaNorris 2016). For example, school enrollment and completion rates in several economies in the MNA region exceed the EMDE average. However, education reforms continue to be needed to address poor scores on international tests and pervasive skills mismatches in the labor market (World Bank 2008 and 2013).

Reform payoffs may take more time to materialize than in the stylized scenarios discussed here. There is some evidence that reforms have had the largest growth dividends when they were well-timed - at least in the context of advanced economies. For example, labor market reforms may lift growth more during economic upswings, when job entrants can more easily find jobs appropriate to their skills, than downturns (IMF 2016b). 
Figure 1. Global Growth

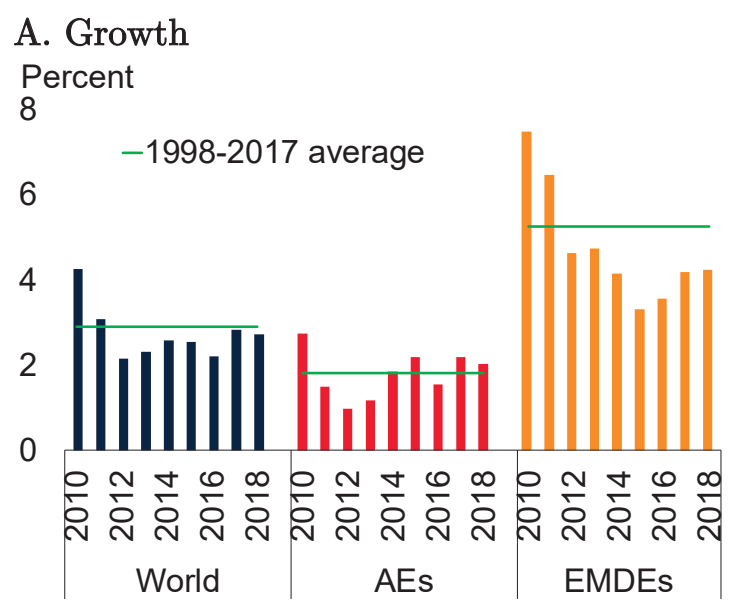

\section{B. Potential growth}

Percent

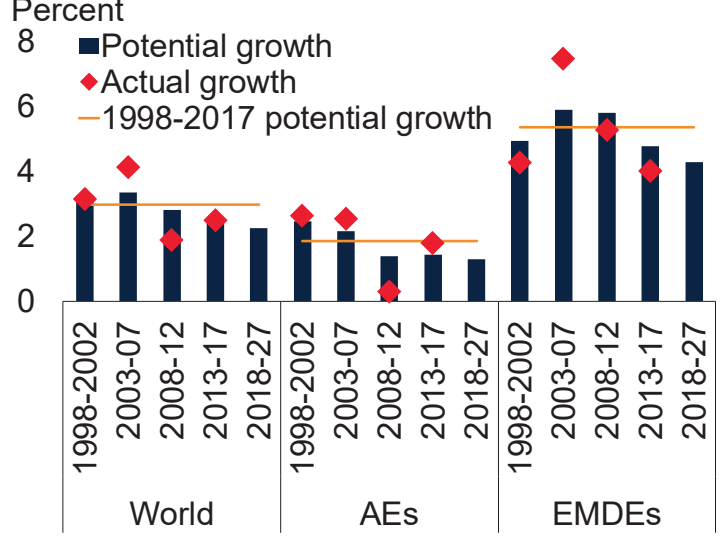

Sources: Penn World Tables, World Bank.

A. Sample of 181 countries.

B. Based on production function approach, GDP-weighted averages for a sample of 30 advanced economies and 50 EMDEs. 
Figure 2. Evolution of Potential Growth

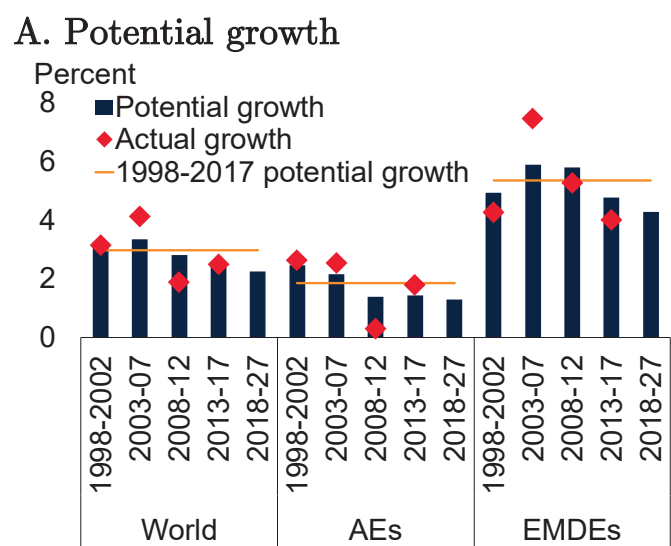

C. Contribution of potential growth and business cycle to actual growth

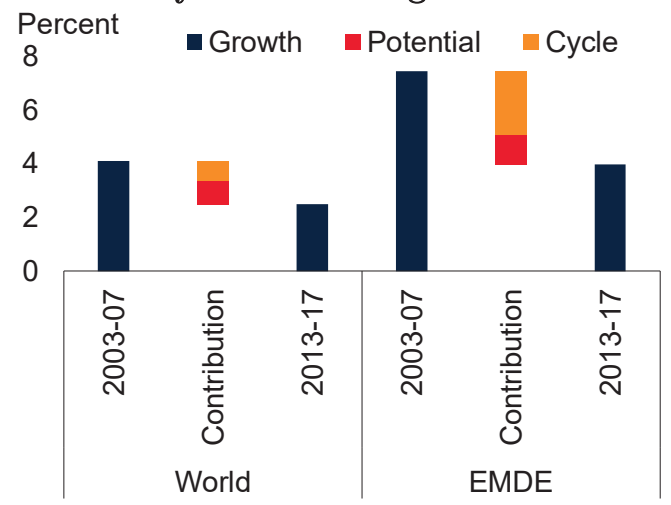

E. Per capita potential growth

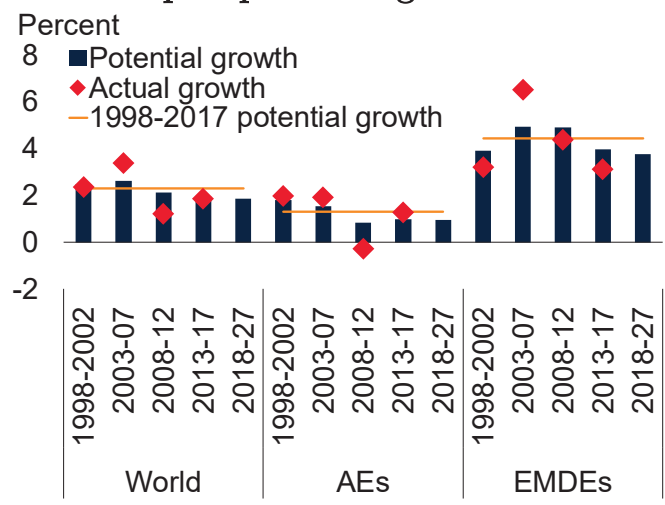

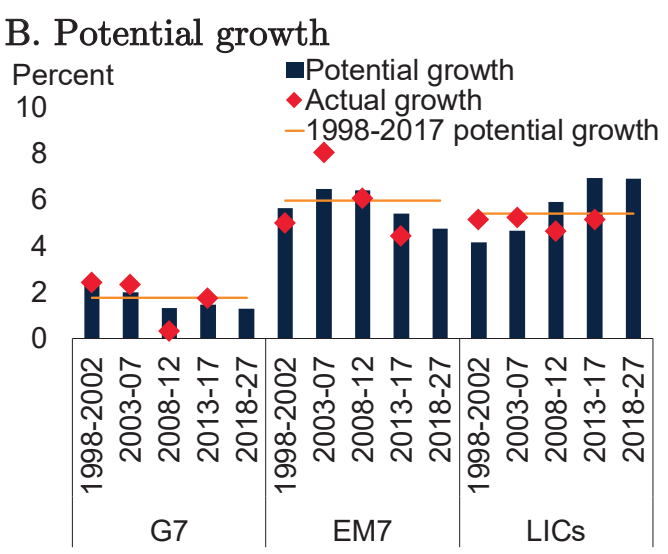

D. Share of economies and GDP with potential growth below 1998-2017 average

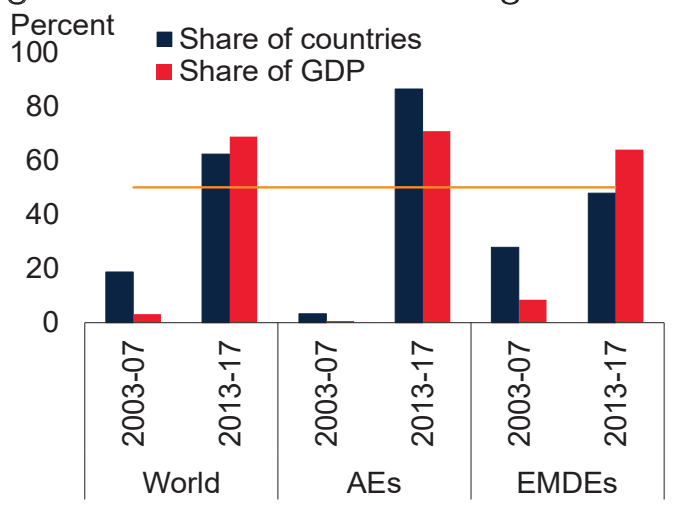

F. Per capita potential growth

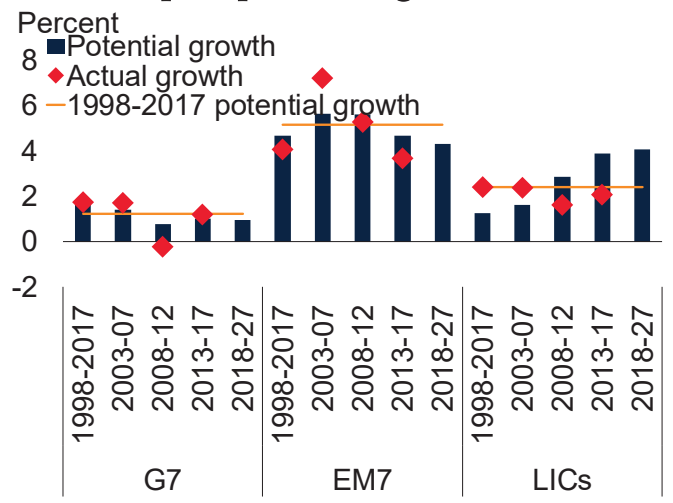

Sources: Penn World Tables, World Bank.

Notes: Based on potential growth derived using production function approach.

A. B. C. E. F. GDP-weighted average. A. C. E. Sample includes 30 advanced and 50 emerging market and developing economies. B. F. G7 includes Canada, France, Germany, Italy, Japan, the United Kingdom and the United States. EM7 includes Brazil, China, India, Indonesia, Mexico, Russia, and Turkey. LICs includes 6 countries.

C. Blue bars denote average actual global growth during 2003-07 and 2013-17. Red bars denote the contribution of global potential growth to the change in actual growth between the two five-year periods; orange bars denote contribution of the cyclical component of global growth to change in actual global growth between the two five-year periods. D. Number of economies and their share of global GDP among 30 advanced economies and 50 EMDEs with potential growth in each period below its longer-term average (19982017). Horizontal line indicates 50 percent. 
Figure 3. Regional Potential Growth

\section{A. Potential growth in EMDE regions}

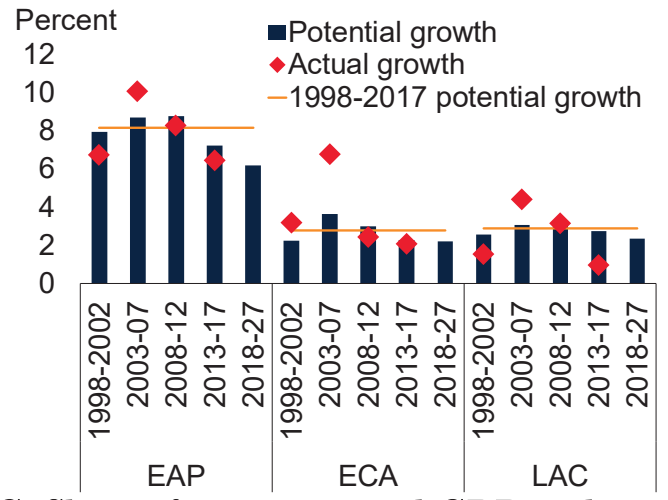

C. Share of economies and GDP with potential growth below 1998-2017 average in EMDE regions

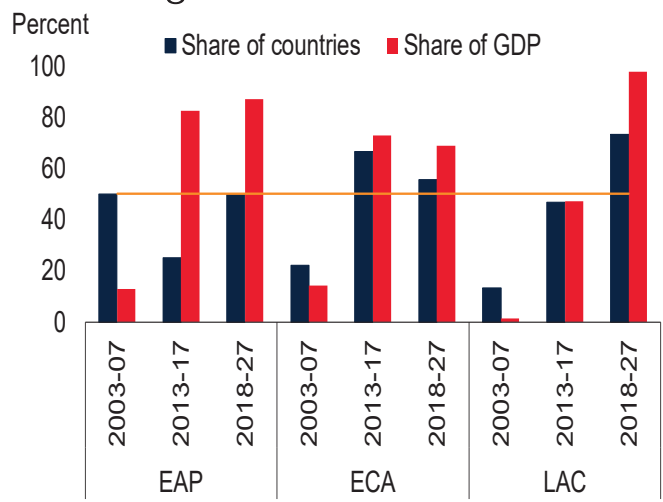

\section{B. Potential growth in EMDE regions}

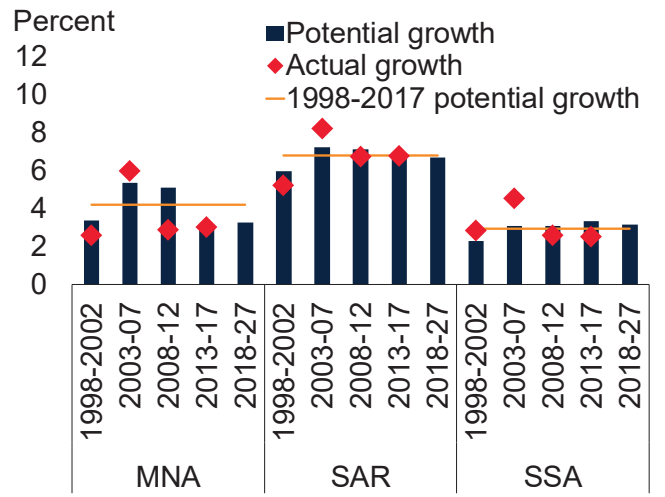

D. Share of economies and GDP with potential growth below 1998-2017 average in EMDE regions

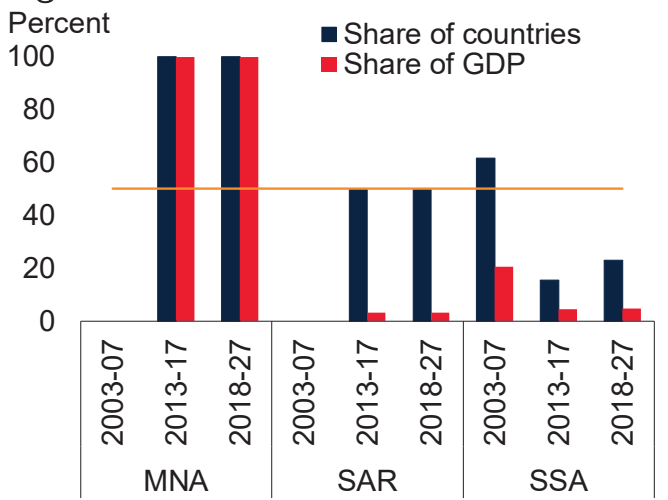

Sources: Penn World Tables, World Bank.

Notes: EAP $=$ East Asia and Pacific, ECA = Europe and Central Asia,

$\mathrm{LAC}=$ Latin America and the Caribbean, MNA = Middle East and North Africa, SAR = South Asia, and SSA = Sub-Saharan Africa.

A. B. GDP-weighted averages using potential growth estimate based on production function approach.

C. D. Number of economies and their share of GDP in the region among 50 EMDEs with potential growth in each region. 
Figure 4. Drivers of Potential Growth

A. Contributions to potential growth

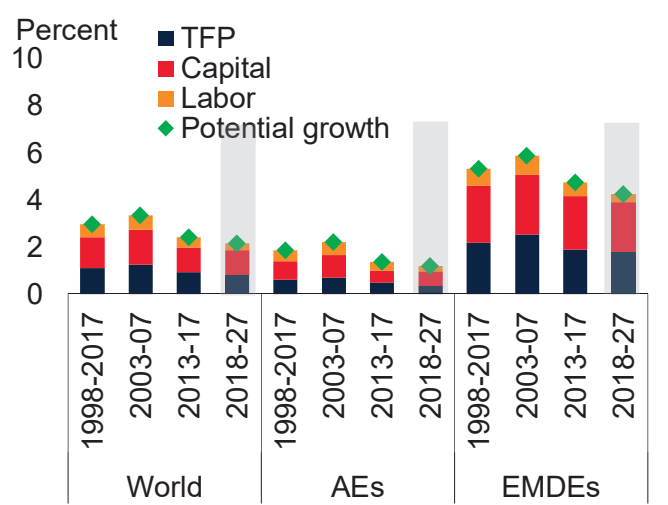

C. Contributions to regional potential growth

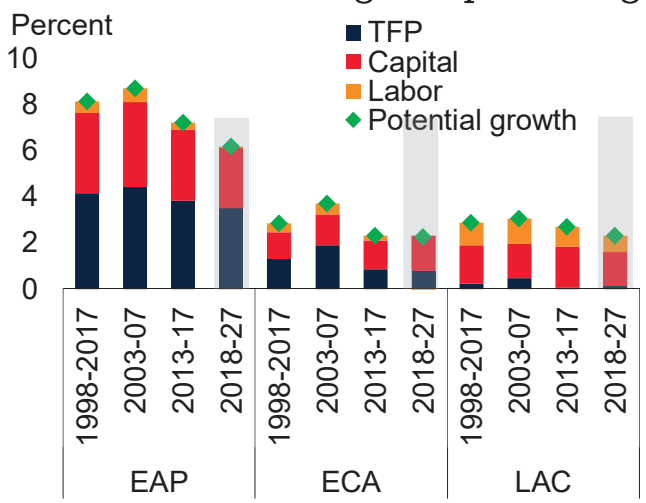

B. Contributions to potential growth in EMDE

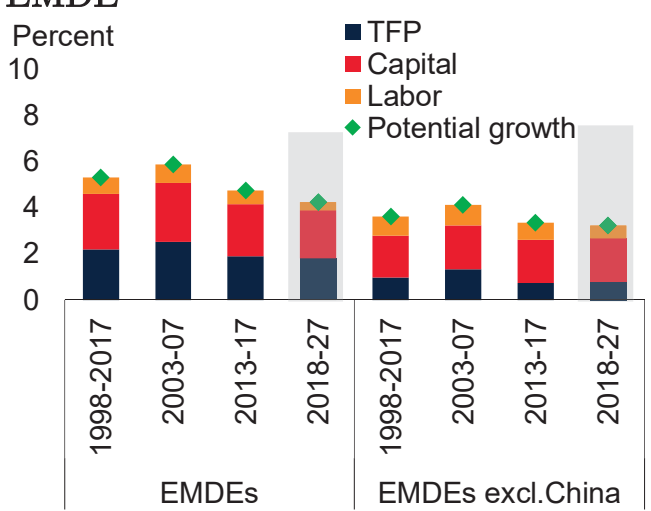

D. Contributions to regional potential growth

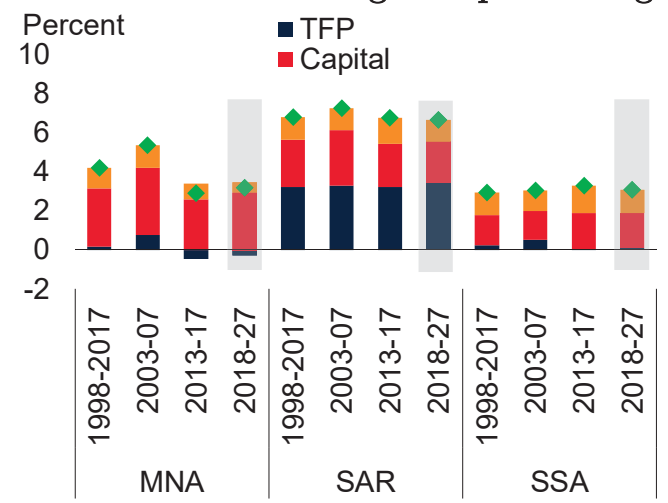

Sources: Penn World Tables, World Bank.

Notes: GDP-weighted averages of production function-based potential growth estimates. TFP growth stands for total factor productivity growth.

A.B. Sample includes 30 advanced economies and 50 EMDEs.

C.D. Regional samples include largest available sample for each region to ensure broad-based coverage. $\mathrm{EAP}=$ East Asia and Pacific, ECA $=$ Europe and Central Asia,

$\mathrm{LAC}=$ Latin America and the Caribbean, MNA = Middle East and North Africa, SAR = South Asia, and SSA = Sub-Saharan Africa. 
Figure 5. Total Factor Productivity Growth

A. Average TFP growth

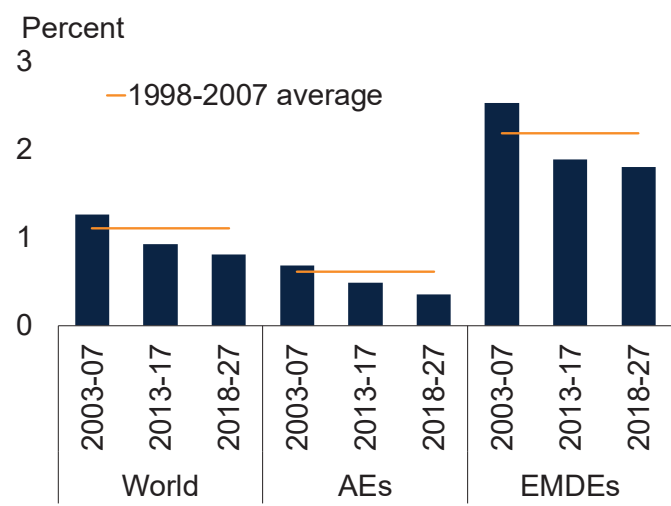

B. Share of economies and GDP with TFP growth below its longer-term average

Percent - Share of countries

100 Share of GDP

80

60

40

20

0

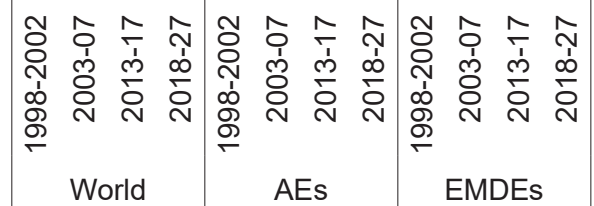

Sources: Penn World Tables, World Bank.

Note: TFP growth stands for total factor productivity growth. This figure refers to potential TFP growth.

A. GDP-weighted average of total factor productivity growth. Includes 50 EMDEs and 30 advanced economies.

B. Number of economies among 30 advanced economies and 50 EMDEs in which potential total factor productivity growth is lower than its longer-term average (1998-2017).

Figure 6. Investment Growth

\section{A. Investment growth}

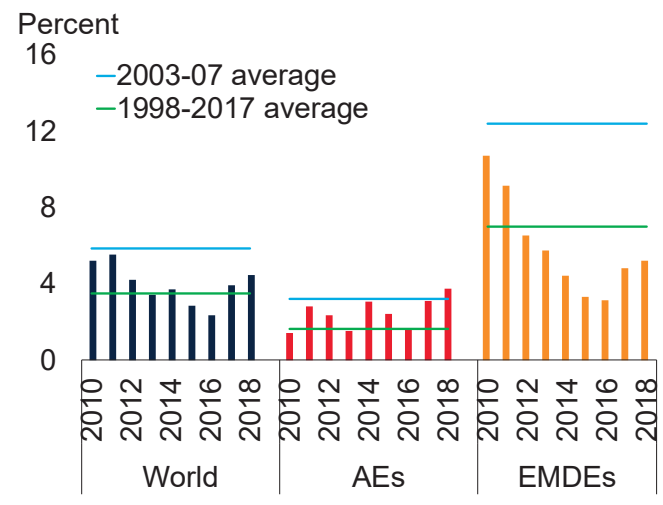

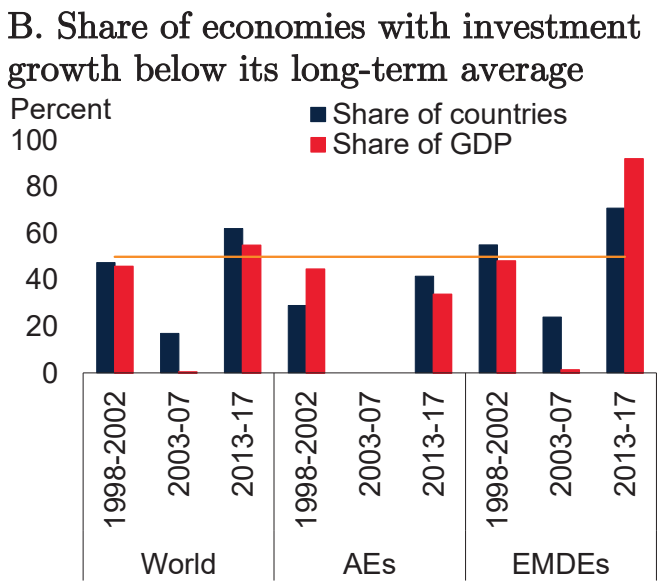

Sources: Penn World Tables, World Bank.

A. Investment-weighted averages. For a sample of 37 advanced economies and 145 EMDEs.

B. Share of 139 countries in which investment growth is below the longer-term average (1998-2017). 
Figure 7. Demographics

A. Impact of 1 percentage point higher growth of working age population share on per capita GDP growth

\section{Percent}

3

1

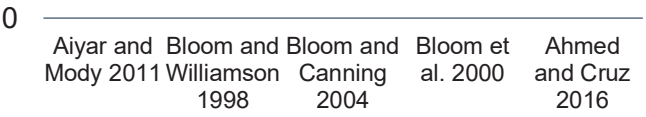

\section{Working-age population}

Percent of total population

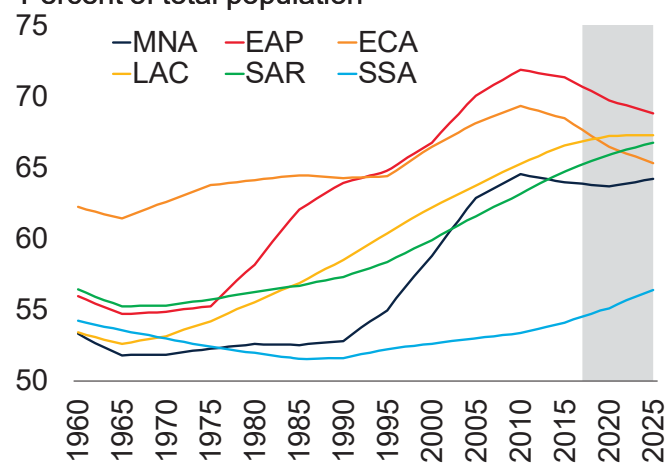

E. EMDE potential growth and contributions

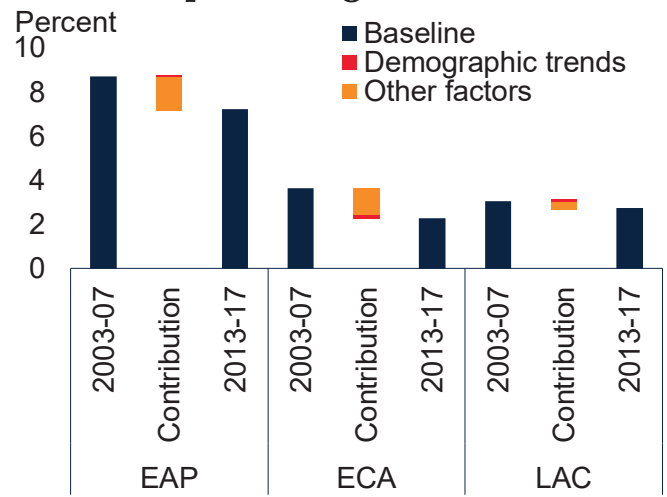

\section{B. Working-age population}

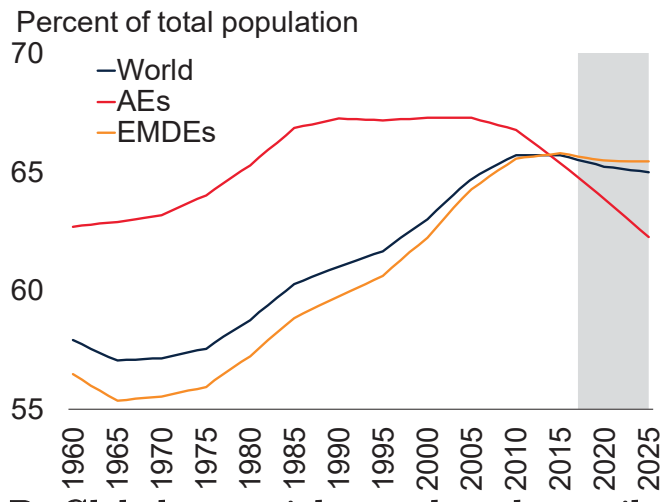

D. Global potential growth and contributions

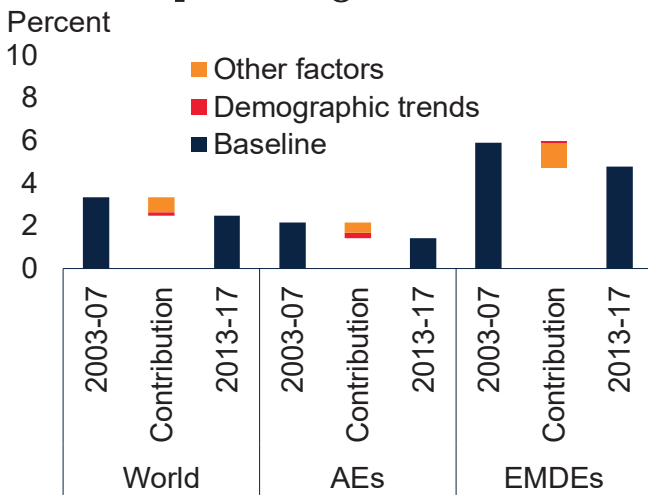

F. EMDE potential growth and contributions

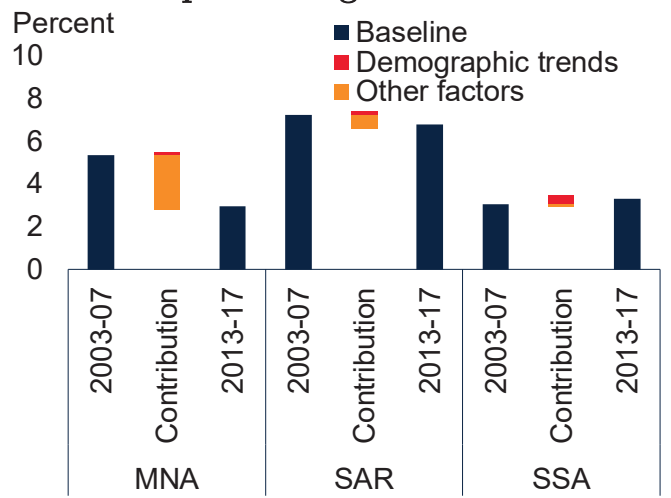

Source: United Nations World Population Prospects: The 2017 Revision.

Note: $\mathrm{EAP}=$ East Asia and Pacific, ECA = Europe and Central Asia,

LAC = Latin America and the Caribbean, MNA = Middle East and North Africa, SAR = South Asia, and SSA = Sub-Saharan Africa. A. The sample of each study differs from each other. Aiyar and Mody (2011): Indian states,

1961-2001; Bloom and Williamson (1998): 78 countries, 1965-90; Bloom and Canning (2004):

Over 70 countries, 1965-95; Bloom et al. (2000): 70 countries, 1965-90; Amer and Cruz (2016):

160 countries, 1960-2010. B.C. Population weighted averages. The working-age population is defined as people aged 15-64 years. D. -F. GDP-weighted averages. Other factors include contribution from policy changes, cohort effects, changes in population growth, convergence-driven productivity growth, and investment. "Contribution" reflects percentage-point changes between the averages of 2003-07 and 2013-17. 
Figure 8. Potential Growth Prospects

\section{A. Potential growth}

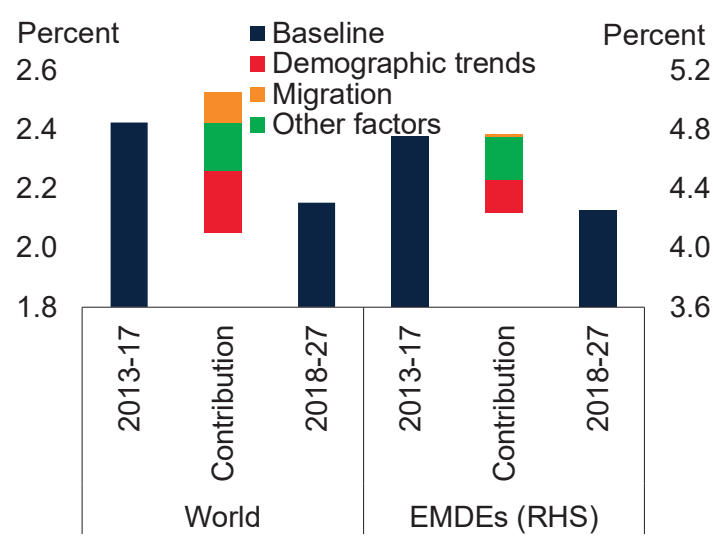

\section{B. Share of countries and GDP of countries with potential growth in 2018-27 below its longer-term average \\ $\begin{array}{ll}\text { Percent } & \text { Share of countries } \\ 100 & \text { Share of GDP }\end{array}$}

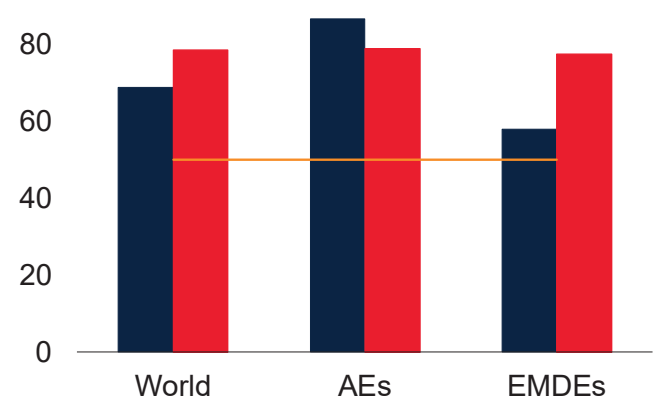

Source: World Bank estimates.

A. GDP-weighted averages. Derived using the production function-based potential growth. "Other factors" reflects declining population growth, convergence-related productivity growth, policy changes, cohort effects, and a slowdown in investment growth relative to output growth. "Contribution" reflects the percentage-point changes between the averages of

2013-17 and 2018-27.

B. Share of countries and share of GDP of 80 countries in which potential growth in 2018-27 is below longer-term average potential growth (1998-2017), in percent of all countries or global GDP among 80 advanced economies and EMDEs. Horizontal line indicates 50 percent.

Source: United Nations World Population Prospects: The 2017 Revision.

Note: $\mathrm{EAP}=$ East Asia and Pacific, ECA = Europe and Central Asia,

$\mathrm{LAC}=$ Latin America and the Caribbean, MNA = Middle East and North Africa, SAR = South Asia, and SSA = Sub-Saharan Africa. A. The sample of each study differs from each other. Aiyar and Mody (2011): Indian states,

1961-2001; Bloom and Williamson (1998): 78 countries, 1965-90; Bloom and Canning (2004):

Over 70 countries, 1965-95; Bloom et al. (2000): 70 countries, 1965-90; Amer and Cruz (2016):

160 countries, 1960-2010. B.C. Population weighted averages. The working-age population is defined as people aged 15-64 years. D. -F. GDP-weighted averages. Other factors include contribution from policy changes, cohort effects, changes in population growth, convergence-driven productivity growth, and investment. "Contribution" reflects percentage-point changes between the averages of 2003-07 and 2013-17. 
Figure 9. Policies to Stem Declining Potential Growth

A. Global potential growth under reform scenarios

Percent $\square$ Pension reforms

3.5 Labor market reforms

3.0 Education and health improvements

3.0 Fill investment needs

2.5

- Baseline

2.0

1.5

1.0

0.5

0.0
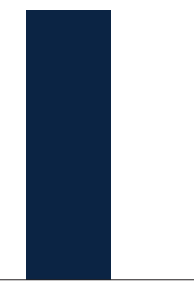

2013-17

2018-27
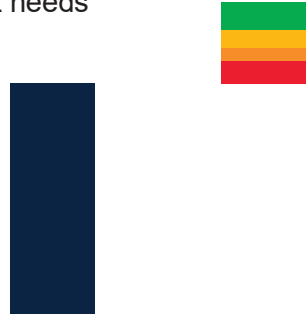

C. EMDE potential growth under reform scenarios

Percent $\square$ Pension reforms

12 Labor market reforms

10 Education and health improvements

8 - Fill investment needs

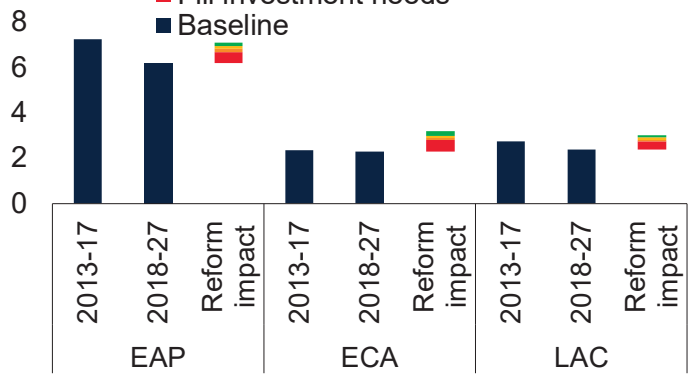

Source: World Bank estimates.

Note: GDP-weighted averages.
B. EMDE potential growth under reform scenarios

Percent $\quad$ Pension reforms

$5.5 \quad$ Labor market reforms

Education and health improvements

5.0

4.5

4.0

3.5

3.0

2.5

2.0 - Fill investment needs

\section{Baseline}

5

\section{5}

0

5

2013-17 2018-27 Reform impact

D. EMDE potential growth under reform scenarios

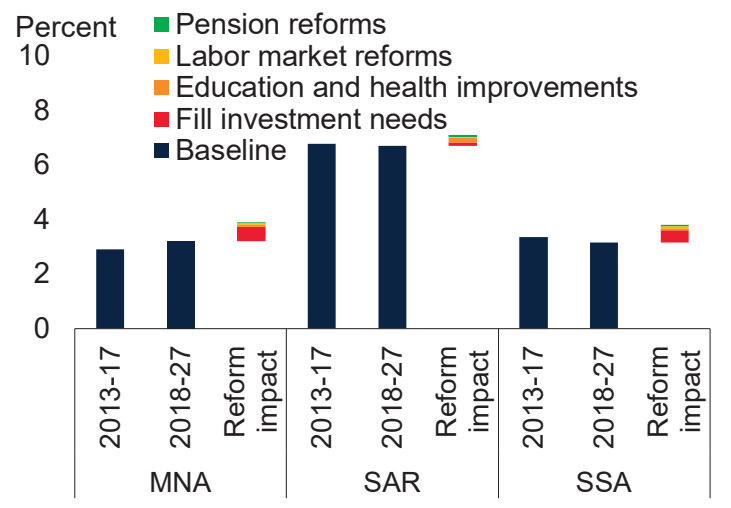


Table 1. Sample and Region Coverage

Advanced Economies

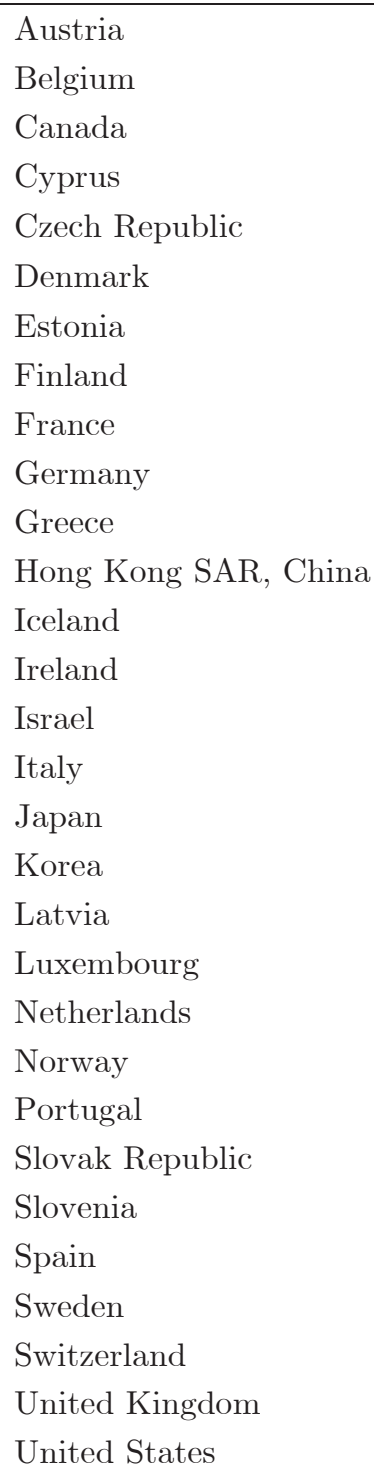

Emerging Market and Developing Economies

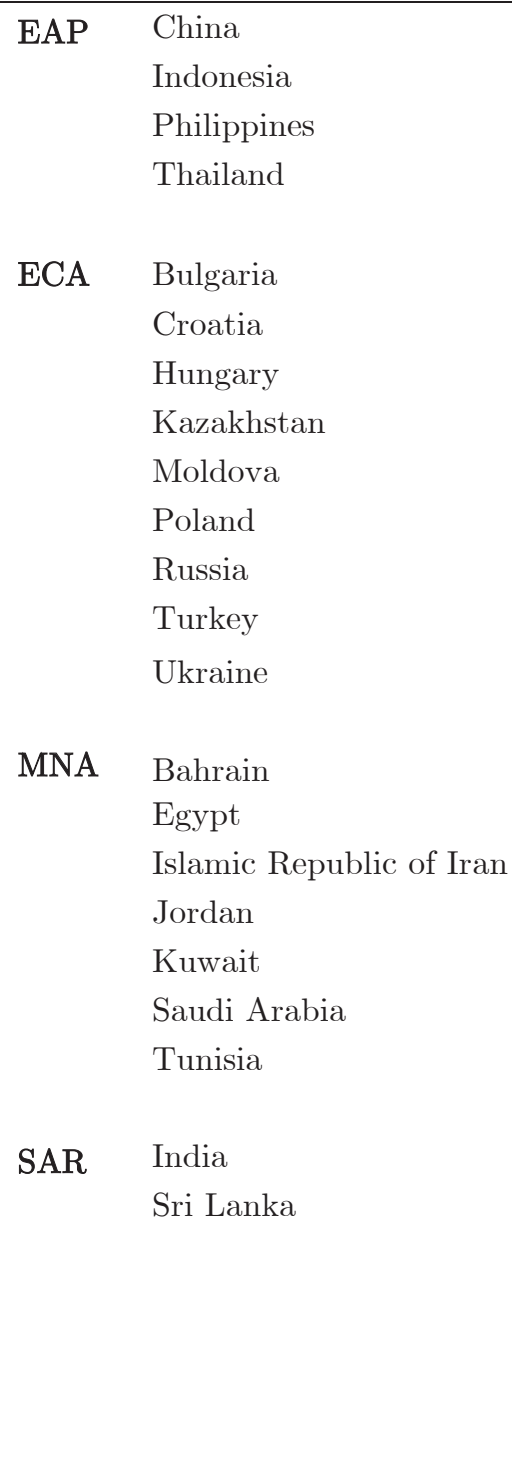

LAC

Argentina

Barbados

Brazil

Chile

Colombia

Costa Rica

Ecuador

Guatemala

Honduras

Jamaica

Mexico

Panama

Paraguay

Peru

Uruguay

SSA Benin

Botswana

Cameroon

Côte d Ivoire

Kenya

Lesotho

Mauritius

Mozambique

Niger

Rwanda

Senegal

South Africa

Swaziland 


\section{References}

Acemoglu, D., and P. Restrepo. 2016. "The Race between Machine and Man: Implications of Technology for Growth, Factor Shares and Employment," NBER Working Paper 22252 (Cambridge, Mass.: National Bureau of Economic Research).

2017a. "Low-Skill and High-Skill Automation," MIT Department of Economics Working Paper 17-12 (Cambridge, Mass.: Massachusetts Institute of Technology).

—. 2017b. "Robots and Jobs: Evidence from U.S. Labor Markets," NBER Working Paper 23285 (Cambridge, Mass.: National Bureau of Economic Research).

2017c. "Secular Stagnation? The Effect of Aging on Economic Growth in the Age of Automation," NBER Working Paper 23077 (Cambridge, Mass.: National Bureau of Economic Research).

Asian Development Bank. 2016. Asian Development Outlook 2016: Asia's Potential Growth. Report. Manila.

Adler, G., R. A. Duval, D. Furceri, S. Kilic Celik, K, Koloskova, and M. PoplawskiRibeiro. 2017. "Gone with the Headwinds: Global Productivity," Staff Discussion Note 17/04 (Washington, D.C.: International Monetary Fund).

Afonso, A., and J. T. Jalles. 2012. "Fiscal Volatility, Financial Crises and Growth," ISEG Economics Working Paper 06/2012/DE/UECE 2012/06 (Lisbon: Lisbon School of Economics and Management, Department of Economics, University of Lisbon).

Aiyar, S., and A. Mody. 2011. "The Demographic Dividend: Evidence from the Indian States," IMF Working Paper 11/38 (Washington, D.C.: International Monetary Fund).

Alfaro, P., D. K. Evans, and P. Holland. 2015. "Extending the School Day in Latin America and the Caribbean," Policy Research Working Paper 7309 (Washington, D.C.: World Bank).

Baily, M. N., and N. Montalbano. 2016. "Why Is U.S. Productivity Growth So Slow? Possible Explanations and Policy Responses," Hutchins Center Working Paper 22 (Brookings Institution), September.

Banerji, A., V. Crispolti, E. Dabla-Norris, R. A. Duval, Christian H. Ebeke, D. Furceri, T. Komatsuzaki, and T. Poghosyan. 2017. "Labor and Product Market Reforms in Advanced Economies: Fiscal Costs, Gains, and Support," IMF Staff Discussion Note 17/03 (Washington, D.C.: International Monetary Fund).

Barbiero, O., and B. Cournede. 2013. "New Econometric Estimates of Long-Term Growth Effects of Different Areas of Public Spending," OECD Economics Department Working Paper 1100 (Paris: Organisation for Economic Co-operation and Development).

Barro, R. 2000. "Inequality and Growth in a Panel of Countries." Journal of Economic Growth 5, no. 1, pp. 5-32.

Betcherman, G. 2014. "Labor Market Regulations: What Do We Know about Their Impacts in Developing Countries?" World Bank Research Observer 30, no. 1, pp. 124-53. 
Betcherman, G., A. Dar, and K. Olivas. 2004. "Impacts of Active Labor Market Programs: New Evidence from Evaluations with Particular Attention to Developing and Transition Countries," Social Protection and Labor Policy and Technical Note 29142 (Washington, D.C.: World Bank).

Bloom, D. E., and D. Canning. 2004. "Global Demographic Change: Dimensions and Economic Significance," NBER Working Paper 10817 (Cambridge, Mass.: National Bureau of Economic Research).

Bloom, D. E., D. Canning, and G. Fink. 2010. "Implications of Population Ageing for Economic Growth." Oxford Review of Economic Policy 26, no. 4, pp. 583-612.

Bloom, D. E., D. Canning, G. Fink, and J. E. Finlay. 2007. "Fertility, Female Labor Force Participation, and the Demographic Dividend," NBER Working Paper 13583 (Cambridge, Mass.: National Bureau of Economic Research).

Bloom, D. E., D. Canning, L. Hu, Y. Liu, A. Mahal, and W. Yip. 2010. "The Contribution of Population Health and Demographic Change to Economic Growth in China and India." Journal of Comparative Economics 38, pp. 17-33.

Bradley, E. H., S. Pallas, C. Bashyal, P. Berman, and L. Curry. 2010. "Developing Strategies for Improving Health Care Delivery: Guide to Concepts, Determinants, Measurement, and Intervention Design," Health, Nutrition and Population Discussion Paper 59885 (Washington, D.C.: World Bank).

Brudevold-Newman, A., M. Honorati, P. Jakiela, and O. W. Ozier. 2017. "A Firm of One's Own: Experimental Evidence on Credit Constraints and Occupational Choice," IZA Discussion Paper 10583 (Bonn: IZA Institute for Labor Economics).

Bussolo, M., J. Koettl, and E. Sinnott. 2015. Golden Aging: Prospects for Healthy, Active, and Prosperous Aging in Europe and Central Asia (Washington, D.C.: World Bank).

Calderón, C., and L. Servén. 2010."Infrastructure and Economic Development in SubSaharan Africa." Journal of African Economies 19 (S1): i13-87.

- 2010. "Infrastructure in Latin America." Policy Research Working Paper 5317. Washington, DC.

- 2014. "Infrastructure, Growth, and Inequality: An Overview." Policy Research Working Paper 7034. World Bank, Washington, DC.

Card, D., J. Kluve, and A. Weber. 2010. "Active Labour Market Policy Evaluations: A Meta-Analysis." Economic Journal 120, no. 548, pp. F452-77.

Castro, V. 2011. "The Impact of the European Union Fiscal Rules on Economic Growth." Journal of Macroeconomics 33, no. 2, pp. 313-26.

Cette, G., J. Fernald, and B. Mojon. 2016. "The Pre-Great Recession Slowdown in Productivity." European Economic Review 88, pp. 3-20.

Cirera, X., and W. F. Maloney. 2017. The Innovation Paradox (Washington, D.C.: World Bank). 
Connelly, R. 1992. "The Effect of Child Care Costs on Married Women's Labor Force Participation." Review of Economics and Statistics 74, no. 1, pp. 83-90.

Corrado, C., and C. Hulten. 2010. "How Do You Measure a 'Technological Revolution'?" American Economic Review 100, no. 2, pp. 99-104.

Cruz, M. and S. Ahmed. 2016. "On the Impact of Demographic Change on Growth, Savings, and Poverty." World Bank Policy Research Paper 7805, World Bank, Washington, DC.

Dabla-Norris, E., G. Ho, and A. Kyobe. 2015. "Structural Reforms and Productivity Growth in Emerging Market and Developing Economies," IMF Working Paper 16/15 (Washington, D.C.: International Monetary Fund).

Dabla-Norris, E. 2016. Structural Reforms and Productivity Growth in Emerging Market and Developing Economies. Washington, D.C.: International Monetary Fund.

Dabla-Norris, E., M. S. Guo, M. V. Haksar, M. Kim, M. K. Kochhar, K. Wiseman, and A. Zdzienicka. 2015. "The New Normal: A Sector-Level Perspective on Productivity Trends in Advanced Economies," IMF Staff Discussion Note (Washington, D.C.: International Monetary Fund).

Das, J., A. Chowdhury, R. Hussam, and A. V. Banerjee. 2016. "The Impact of Training Informal Health Care Providers in India: A Randomized Controlled Trial." Science 354, no. 6308 , p. 7384 .

Devarajan, S., V. Swaroop, and H. F. Zou. 1996. "The Composition of Public Expenditure and Economic Growth." Journal of Monetary Economics 37, no. 2, pp. 313-44.

Dollar, D., T. Kleineberg, and A. Kraay. 2013. "Growth Is Still Good for the Poor," Policy Research Working Paper 6568 (Washington, D.C.: World Bank).

Eastwood, R., and M. Lipton. 2011. "Demographic Transition in Sub-Saharan Africa: How Big Will the Economic Dividend Be?" Population Studies 65, pp. 9-35.

European Bank for Reconstruction and Development. 2014. Transition Report. London.

European Commission. 2015. The 2015 Aging Report: Economic and Budgetary Projections for the 28 EU Member States (2013-2060). Report. Brussels.

Evans, D. K., and A. Popova. 2016. "What Really Works to Improve Learning in Developing Countries? An Analysis of Divergent Findings in Systematic Reviews." World Bank Research Observer 31, no. 2, pp. 242-70.

Gertler, P., and C. Vermeersch. 2012. "Using Performance Incentives to Improve Health Outcomes," Policy Research Working Paper 6100 (Washington, D.C.: World Bank).

Glewwe, P., and K. Muralidharan. 2015. "Improving School Education Outcomes in Developing Countries: Evidence, Knowledge Gaps, and Policy Implications," Research on Improving Systems of Education (RISE) Working Paper 15/001 (University of Oxford).

Goldin, C. 1994. "The U-Shaped Female Labor Force Function in Economic Development and Economic History," NBER Working Paper 4707 (Cambridge, Mass.: National Bureau of Economic Research). 
Gordon, R. 2013. "U.S. Productivity Growth: The Slowdown Has Returned after a Temporary Revival." International Productivity Monitor 25, pp. 13-19.

Gould, E. D. 2007. "Cities, Workers, and Wages: A Structural Analysis of the Urban Wage Premium." Review of Economic Studies 74, no. 2, pp. 477-506.

Greenwood, J., Z. Hercowitz, and P. Krusell. 1997. "Long-Run Implications of Investment-Specific Technological Change." American Economic Review 87, no. 3, pp. $342-62$.

Grossman, G. M., and E. Helpman. 1991. "Quality Ladders in the Theory of Growth." Review of Economic Studies 58, no. 1, pp. 43-61.

Gupta, S., B. Clements, E. Baldacci, and C. Mulas-Granados. 2005. "Fiscal Policy, Expenditure Composition, and Growth in Low-Income Countries." Journal of International Money and Finance 24, no. 3, pp. 441-63.

Islamaj, E., M. A. Kose, F. Ohnsorge, and S. L. Ye. 2017. "Explaining Recent Investment Weakness: Causes and Implications." Emerging Market Finance and Trade 55(8): 170921.

Hanushek, E. A., and L. Woessmann. 2008. "The Role of Cognitive Skills in Economic Development." Journal of Economic Literature 46, no. 3, pp. 607-68.

Higgins, M., and J. G. Williamson. 1997. "Age Structure Dynamics in Asia and Dependence on Foreign Capital." Population and Development Review 23, no. 2, pp. 26193.

Hill, M. A. 1983. "Female Labor Force Participation in Developing and Developed Countries - Consideration of the Informal Sector." Review of Economics and Statistics 65, no. 3 , pp. 459-68.

Huidrom, R., M. A. Kose, and F. Ohnsorge. 2017. "Spillovers from Major Emerging Markets," Policy Research Working Paper 8093 (Washington, D.C.: World Bank).

International Monetary Fund. 2004. "How Will Demographic Change Affect the Global Economy?" in World Economic Outlook September 2004. Report. Washington, D.C.

2015. "Where Are We Headed? Perspectives on Potential Growth," in World Economic Outlook April 2015. Report. Washington, D.C.

- 2016a. "Fiscal Policies for Innovation and Growth," in Acting Now, Acting Together, Fiscal Monitor April 2016. Report. Washington, D.C.

- 2016b. "Time for a Supply-Side Boost? Macroeconomic Effects of Labor and Product Market Reforms in Advanced Economies," in World Economic Outlook April 2016. Report. Washington, D.C.

Jones, Charles. 2016. "The Facts of Economic Growth," in Handbook of Macroeconomics, vol. 2A, edited by J. Taylor and H. Uhlig (Amsterdam: Elsevier).

Kelley, A. C., and R. M. Schmidt. 1995. "Aggregate Population and Economic Growth Correlations: The Role of the Components of Demographic Change." Demography 32, no. 4, pp. 543-55. 
2005. "Evolution of Recent Economic Demographic Modelling: A Synthesis." Journal of Population Economics 18: 275-300.

—. 2007. "A Century of Demographic Change and Economic Growth: The Asian Experience in Regional and Temporal Perspective," in Population Change, Labor Markets and Sustainable Growth: Towards a New Economic Paradigm, edited by A. Mason and M. Yamaguchi (Amsterdam: Elsevier).

Kilic Celik, S., M. A. Kose, F. Ohnsorge, and M. Y. Some. Forthcoming. "A CrossCountry Database of Potential Growth." Washington, D.C.: World Bank.

Kilic Celik, S., M. A. Kose, and F. Ohnsorge. 2020. "Subdued Potential Growth: Sources and Remedies." In Kim, H.-W. and Z. Qureshi (eds). 2020. Growth in a Time of Change: Global and Country Perspectives on a New Agenda. Brookings Institution, Washington, D.C.

Killingsworth, M. R., and J. J. Heckman. 1986. "Female Labor Supply: A Survey." Handbook of Labor Economics 1, pp. 103-204.

Kremer, M., C. Brannen, and R. Glennerster. 2013. "The Challenge of Education and Learning in the Developing World." Science 340, no. 6130, pp. 297-300.

Kose, M. A., F. Ohnsorge, Y. S. Lei, and E. Islamaj. 2017. "Weakness in Investment Growth: Causes, Implications and Policy Responses," Policy Research Working Paper 7990 (Washington, D.C.: World Bank).

Kose, M. A. and F. Ohnsorge. 2019. A Decade after the Global Recession: Lessons and Challenges for Emerging and Developing Economies. Washington, D.C., World Bank.

Kose, M. A., P. Nagle, F. Ohnsorge, and N. Sugawara. 2019. Global Waves of Debt: Causes and Consequences. Washington, D.C., World Bank.

Kose, M. A., F. Ohnsorge, and N. Sugawara. Forthcoming. "Global Growth Next Decade: Optimistic Expectations, Disappointing Outcomes." Policy Research Working Paper, World Bank, Washington.

Lucas, R. E., Jr. 1988. "On the Mechanics of Economic Development." Journal of Monetary Economics 22, no. 1, pp. 3-42.

Maeda, A., C. Cashin, J. Harris, N. Ikegami, and M. R. Reich. 2014. Universal Health Coverage for Inclusive and Sustainable Development: A Synthesis of 11 Country Case Studies Directions in Development 88862. (Washington, D.C.: World Bank).

Maestas, N., K. Mullen, and D. Powell. 2016. "The Effect of Population Aging on Economic Growth, the Labor Force and Productivity," NBER Working Paper 22452 (Cambridge, Mass.: National Bureau of Economic Research).

Mincer, J. 1962. "Labor Force Participation of Married Women: A Study of Labor Supply," in Aspects of Labor Economics (Princeton University Press).

Miyazaki, T. 2014. "Fiscal Reform and Fiscal Sustainability: Evidence from Australia and Sweden," Graduate School of Economics Discussion Paper 1407 (Kobe University). 
Organisation for Economic Co-operation and Development. 2014. "Growth Prospects and Fiscal Requirements over the Long Term," OECD Economic Outlook 2014/1 (Paris).

- 2017. Going for Growth (Paris).

2018a. The Future of Education and Skills: Education 2030 (Paris).

Ollivaud, P., Y. Guillemette, and D. Turner. 2016. "The Links between Weak Investment and the Slowdown in OECD Productivity and Potential Output Growth," OECD Economics Department Working Paper 1304 (Paris: Organisation for Economic Cooperation and Development).

Prati, A., M. G. Onorato, and C. Papageorgiou. 2013. "Which Reforms Work and under What Institutional Environment?" Review of Economics and Statistics 95, no. 3, pp. 94668 .

Presbitero, A. F. 2016. "Too Much and Too Fast? Public Investment Scaling-Up and Absorptive Capacity." Journal of Development Economics 120, pp. 17-31.

Prüss-Üstün, A., R. Bos, F. Gore, and J. Bartram. 2008. Safer Water, Better Health: Costs, Benefits and Sustainability of Interventions to Protect and Promote Health (Geneva: World Health Organization).

Ran, T., S. Chen, W. Hui, and Z. Guzhong. 2011. "Paradox of 'Lewis Turning Point' and Coordinated Reforms of China's Hukou-Land-Fiscal System." International Economic Review 3, pp. 120-48.

Ravallion, M., and G. Datt. 2002. "Why Has Economic Growth Been More Pro-Poor in Some States of India than Others?" Journal of Development Economics 68, no. 2, pp. 381-400.

Romer, P. M. 1986. "Increasing Returns and Long-Run Growth." Journal of Political Economy 94, no. 5, pp. 1002-37.

Sakeflaris, P., and D. J. Wilson. 2004. "Quantifying Embodied Technological Change." Review of Economic Dynamics 7, no. 1, pp. 1-26.

Solow, R. M. 1962. "Technical Progress, Capital Formation, and Economic Growth." American Economic Review 52, no. 2, pp. 76-86.

Tsimpo Nkengne, C., A. Etang Ndip, and W. T. Wodon. 2017. "Education and Health Services in Uganda: Quality of Inputs, User Satisfaction, and Community Welfare Levels," Policy Research Working Paper 8116 (Washington, D.C.: World Bank).

United Nations Conference on Trade and Development. 2014. "Investment in SGDs: An Action Plan," in World Investment Report. Report. New York.

United Nations, 2017. World Population Prospects: The 2017 Revision. Department of Economic and Social Affairs, Population Division Report. New York. [DVD edition]

Vashakmadze, E. T., G. Kambou, D. H. C. Chen, B. Nandwa, Y. Okawa, and D. L. Vorisek. 2017. "Regional Dimensions of Recent Weakness in Investment: Drivers, Investment Needs and Policy Responses," Policy Research Working Paper 7991 (Washington, D.C.: World Bank). 
World Bank. 2008. The Road Not Travelled: Education Reform in the Middle East and Africa (Washington, D.C.).

. 2013. Jobs for Shared Prosperity: Time for Action in the Middle East and North Africa (Washington, D.C.). D.C.).

2015. Global Economic Prospects: Having Fiscal Space and Using It (Washington,

. 2017a. Global Economic Prospects: Weak Investment in Uncertain Times (Washington, D.C.).

2017b. Global Economic Prospects: A Fragile Recovery (Washington, D.C.).

2017c. World Development Report: Learning to Realize Education's Promise (Washington, D.C.).

World Economic Forum. 2016. The Future of Jobs Employment, Skills and Workforce Strategy for the Fourth Industrial Revolution. Report. Geneva, January.

Yankow, J. J. 2006. "Why Do Cities Pay More? An Empirical Examination of Some Competing Theories of the Urban Wage Premium." Journal of Urban Economics 60, no. 2, pp. 139-61. 